\title{
Downstream collecting in ciliary suspension feeders: the catch-up principle
}

\author{
Hans Ulrik Riisgård ${ }^{1, *}$, Claus Nielsen ${ }^{2}$, Poul S. Larsen ${ }^{3}$ \\ ${ }^{1}$ Research Centre for Aquatic Biology, Odense University, Hindsholmvej 11, 5300 Kerteminde, Denmark \\ ${ }^{2}$ Zoological Museum, University of Copenhagen, Universitetsparken 15, 2100 Copenhagen, Denmark \\ ${ }^{3}$ Department of Energy Engineering, Fluid Mechanics Section, Technical University of Denmark, Building 403, 2800 Lyngby, \\ Denmark
}

\begin{abstract}
Based on observations of feeding structures and currents in the polychaete Spirorbis tridentatus, the entoproct Loxosoma pectinaricola and the cycliophore Symbion pandora, which all possess compound cilia, it is hypothesized that their capture mechanism is based on the catch-up principle. According to this principle, the compound cilia constitute the pump which generates a flow with suspended particles that enters the ciliary region. In this region the same cilia, during their power stroke, catch up with suspended particles and transfer the particles to a food groove, or a mouth cavity. In the particle-size retention spectrum, the lower limit depends on spacing between cilia in phase, while the upper end depends on cilia length which may or may not allow particles to enter the ciliary region. On the basis of fluid mechanical considerations and literature descriptions of structure and function of the ciliary bands of some rotifers and of the various types of trochophora larvae of annelids, molluscs and entoprocts, it is hypothesized that the feeding mechanisms of these organisms are based on the catch-up principle.
\end{abstract}

KEY WORDS: Feeding structures · Video observations · Velocities of particles · Fluid mechanics · Retention efficiency $\cdot$ Size spectra

\section{INTRODUCTION}

Suspension feeding by means of ciliary bands is widespread among aquatic invertebrates. Four types of capture mechanisms have been recognized so far: (1) upstream collecting, whereby particles are collected on the upstream side of the current-generating band of cilia; (2) ciliary sieving, whereby particles are retained by a mechanical filter formed by a band of stiff cilia distinct from the current-generating band; (3) cirri trapping, whereby eulaterofrontal cirri beat against the current set in motion by current-generating lateral cilia; and (4) downstream collecting, whereby particles are collected on the downstream side of the current-generating ciliary band.

*E-mail: hur@biology.sdu.dk
Upstream collecting ('single-band system') has been described in larvae of phoronids, brachiopods, echinoderms and enteropneusts, and on the tentacles of adult phoronids, brachiopods and pterobranchs (Strathmann et al. 1972, Nielsen 1987, Emlet \& Strathmann 1994). In general, the mechanisms involved in separating food particles from the currents set up by the ciliary bands in upstream collecting organisms are poorly understood. This mechanism is correlated with the presence of only a single band of cilia, which appears to be responsible for both the water transport and particle retention as suggested by Strathmann et al. (1972).

Ciliary sieving by means of stiff (laterofrontal) cilia is now well documented and appears to be restricted to larval and adult ectoproct bryozoans (Strathmann \& McEdward 1986, Riisgård \& Manríquez 1997, Nielsen \& Riisgård 1998). 
Cirri trapping has been disclosed in recent years as the basic particle capture mechanism in the autobranch bivalve Mytilus: transfer of particles in the current created by the lateral cilia are stopped and transferred to the frontal side of the gill filament by the laterofrontal cirri (Nielsen et al. 1993, Riisgård et al. 1996, Silverman et al. 1996a,b, 2000, Riisgård \& Larsen 2000).

Downstream collecting systems ('opposed-band' or 'double-band' systems) have been described in larvae of gastropods, bivalves, polychaetes and entoprocts, in adult sabellid and serpulid polychaetes, entoprocts and in some rotifers (Strathmann et al. 1972, Nielsen \& Rostgaard 1976, Strathmann \& Leise 1979, Gallager 1988, Emlet 1990, Hansen 1991, Emlet \& Strathmann 1994, Mayer 1994, Nielsen 1995). Downstream particle collecting in larvae involves 2 opposed bands of cilia, of which the prototroch (preoral band) carries longer cilia than the opposed metatroch (postoral band). The prototroch beats posteriorly and creates a current for feeding and locomotion. The metatroch beats anteriorly, toward the prototroch. In larvae that have this feeding mechanism (with the exception of the mitraria larva of Owenia), the prototroch consists of compound cilia that may reach lengths of about 30 to $140 \mu \mathrm{m}$ during the development of different species (Nielsen 1987 , Emlet \& Strathmann 1994). Between these parallel ciliary bands lies a food groove (the adoral ciliary zone), with separate cilia that beat toward the mouth. The opposed proto- and metatroch retain particles 'downstream', and the particles are then passed along the food groove to the mouth.

The ciliary feeding structure and function in adult ciliary suspension-feeding polychaetes have been less studied, but direct observations of particle capture in several species and video recordings of the polychaete Sabella penicillus suggest that the basic retention mechanism is similar to that of the larvae (Mayer 1994). Likewise, downstream collecting has been observed in adult entoprocts, whereby the beat of a row of long, compound lateral cilia creates a current between the tentacles and at the same time catches particles from the water. The function of the ciliary bands of the polychaete and entoproct tentacle is comparable to the downstream-collecting, opposed-band system of prototroch, metatroch and adoral ciliary zone of planktotrophic trochophores and veligers. The only major structural difference appears to be that, in the larvae, the protrotroch cilia are longer than the metatroch cilia whereas in the entoproct tentacle the 2 opposed bands consist of compound cilia of equal length (Nielsen \& Rostgaard 1976, Mayer 1994).

Beat of prototroch cilia and particle paths were filmed for molluscan veligers by Strathmann \& Leise (1979), who hypothesized that suspended particles are concentrated when they are caught up by and possibly adhering weakly to the prototroch cilia in their effective stroke (direct interception) and pushed faster than the water. Prototroch cilia in their effective strokes were found to move about 1.5 to 2 times faster than particles travelling in the same arc, and it was suggested that the recovery stroke may act to draw the particles into the food groove, perhaps in cooperation with the current generated by the metatroch. Further substantiation and more solid pieces of evidence for the suggested downstream collecting mechanism have up to now not been procured, although such knowledge is of great importance for a basic understanding of particle capture in one of the major types of metazoan ciliary suspension feeding.

The present work aims at obtaining experimental observations and theoretical background to allow a critical examination of the above 'catch-up hypothesis'. This was done by studying ciliary structure and function of downstream collecting in adults of the serpulid polychaete Spirorbis tridentatus, the entoproct Loxosoma pectinaricola and the cycliophore Symbion pandora, which are all small and sessile and feed by means of compound cilia. These species were chosen in order to obtain information about adult, sessile animals with this type of ciliary bands, which do not have to be tethered for observations, and to obtain good optical conditions for microscope/video observation of the interaction between cilia and particle during the capture event.

\section{MATERIALS AND METHODS}

Specimens of Spirorbis tridentatus (Levinsen) found on loose fronds of the red alga Chondrus crispus from Ellekilde Hage, northern Øresund, Denmark, in November 1998 were used for the transmission electron microscopy (TEM) studies, whereas the specimens observed alive and studied by scanning electron microscopy (SEM) were collected in October 1998 from the wharf ( 0.5 to $1 \mathrm{~m}$ depth; $25 \%$ o $\left.; 8^{\circ} \mathrm{C}\right)$ at Kristineberg Marine Research Station, Sweden; the specimens were kept in water from the collecting site. Loxosoma pectinaricola (Franzén) was obtained from the gills of the polychaete Pectinaria belgica dredged in October 1998 from a muddy bottom at about $40 \mathrm{~m}$ depth between Kristineberg and Lysekil in the Gullmarsfjord, Sweden, $\left(34 \%\right.$ o $\left.\mathrm{S}_{;} 6^{\circ} \mathrm{C}\right)$. The polychaetes with entoprocts attached to the body and gills were kept in running seawater from the open, deep seawater system of the laboratory. Filter-feeding stage specimens of Symbion pandora, obtained from the mouth appendages of the Norway lobster Nephrops norvegicus at Kristineberg Marine Research Station in May 1999, were directly transferred to the observation chamber on an inversed 
microscope for video recording of the feeding process (see below).

Electron microscopy. Specimens of Spirorbis tridentatus used for TEM were removed from the calcareous tubes, narcotized with stovaïn or $7.5 \% \mathrm{MgCl}_{2}$ in distilled water, fixed in $2.5 \%$ glutaraldehyde in $0.1 \mathrm{M}$ cacodylate buffer, postfixed in $1 \% \mathrm{OsO}_{4}$ in the same buffer and embedded in araldite. Specimens of $S$. tridentatus and Loxosoma pectinaricola, both species used for SEM, were narcotized with stovaïn or $7.5 \% \mathrm{MgCl}_{2}$ in distilled water, fixed in 1 to $2 \% \mathrm{OsO}_{4}$ in distilled water, dehydrated in an acetone series, and critical point dried.
Video observations. The feeding process in intact and undisturbed animals was recorded using a video camera (Kappa CF 11/1) attached to an inversed microscope (Labovert FS), and a 50 half-frames per second video recorder (Panasonic NV-FS200 HQ). Individuals were either placed on the bottom of a cylindrical observation chamber placed on the microscope, or they were fixed on the tip of steel wire fastened to a micro-manipulator to allow video recordings in different angles when the animal was lowered into the observation chamber on the microscope. The seawater in the observation chamber contained algal particles

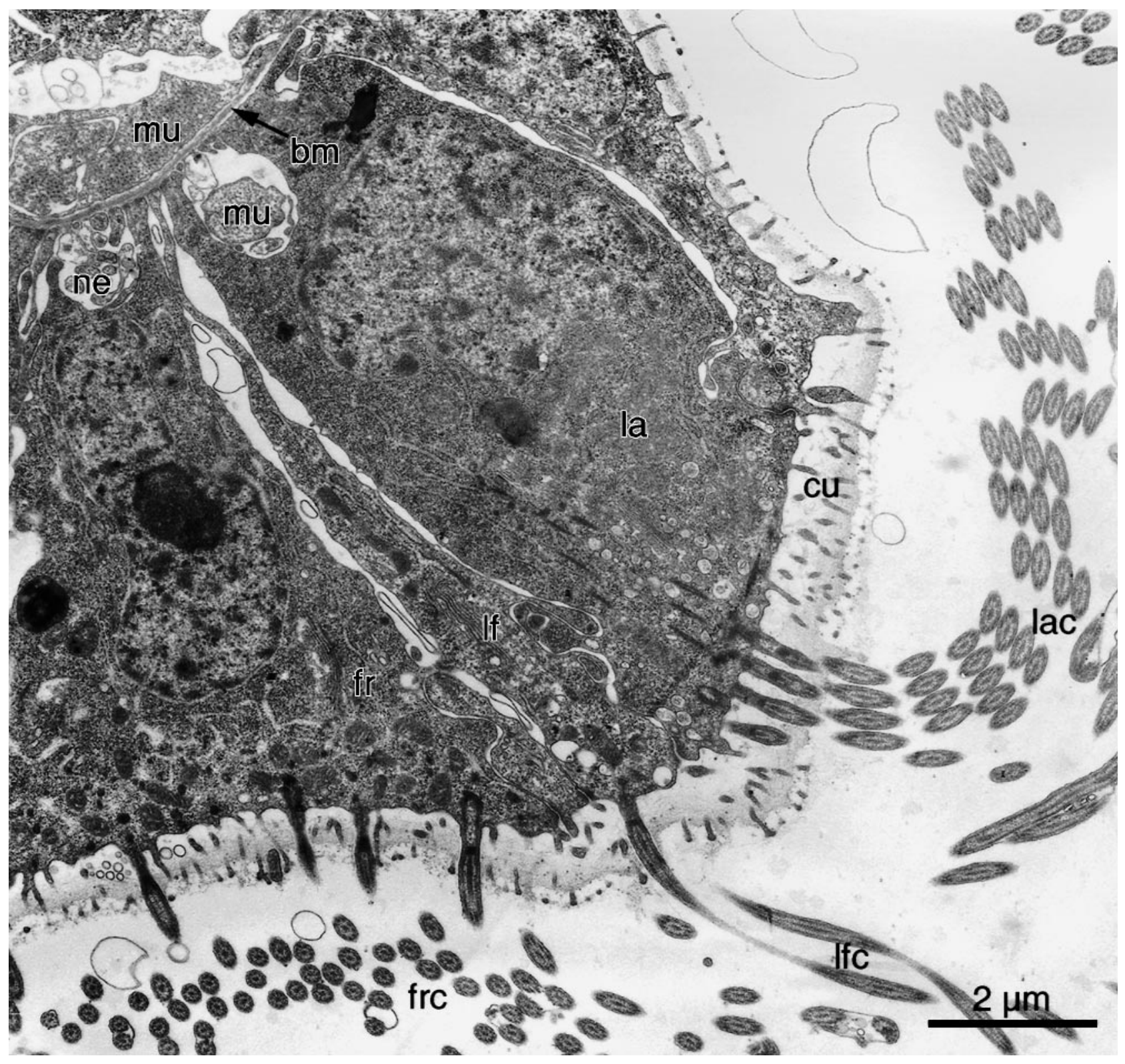

Fig. 1. Spirorbis tridentatus. Transverse section of a pinnule; TEM (bm, basement membrane; cu, cuticle; fr, frontal cell; frc, frontal cilia; la, lateral cell; lac, lateral [compound] cilia; lf, laterofrontal cell; lfc, laterofrontal cilia; mu, muscles; ne, nerve 
(6 $\mu \mathrm{m}$ diameter flagellates Rhodomonas sp.) in a concentration of about 5000 cells $\mathrm{ml}^{-1}$. All observations of Spirorbis tridentatus and Symbion pandora were made at room temperature (about 18 to $20^{\circ} \mathrm{C}$ ) using water from the collection site. Observations of the less temperature-tolerant Loxosoma pectinaricola were made at about 6 to $10^{\circ} \mathrm{C}$ by cooling the microscope stage by means of ice. Captures of particles were traced from their position in successive video frames. The movements were followed by mounting a transparent plastic sheet onto the video screen so that the position of suspended particles could be marked with a pen directly on the sheet, frame by frame. Video pictures could also be copied by means of a video graphic printer (Sony UP-860 CE).

\section{RESULTS AND DISCUSSION}

\section{Feeding structures}

\section{Tentacles of Spirorbis tridentatus}

The serpulid tentacle crown consists of a number of pinnate tentacles, whereby both numbers of tentacles and of pinnules per tentacle increase during growth; also the length of tentacles and pinnules increases, so it becomes almost impossible to make meaningful estimates of the length of the ciliary bands.

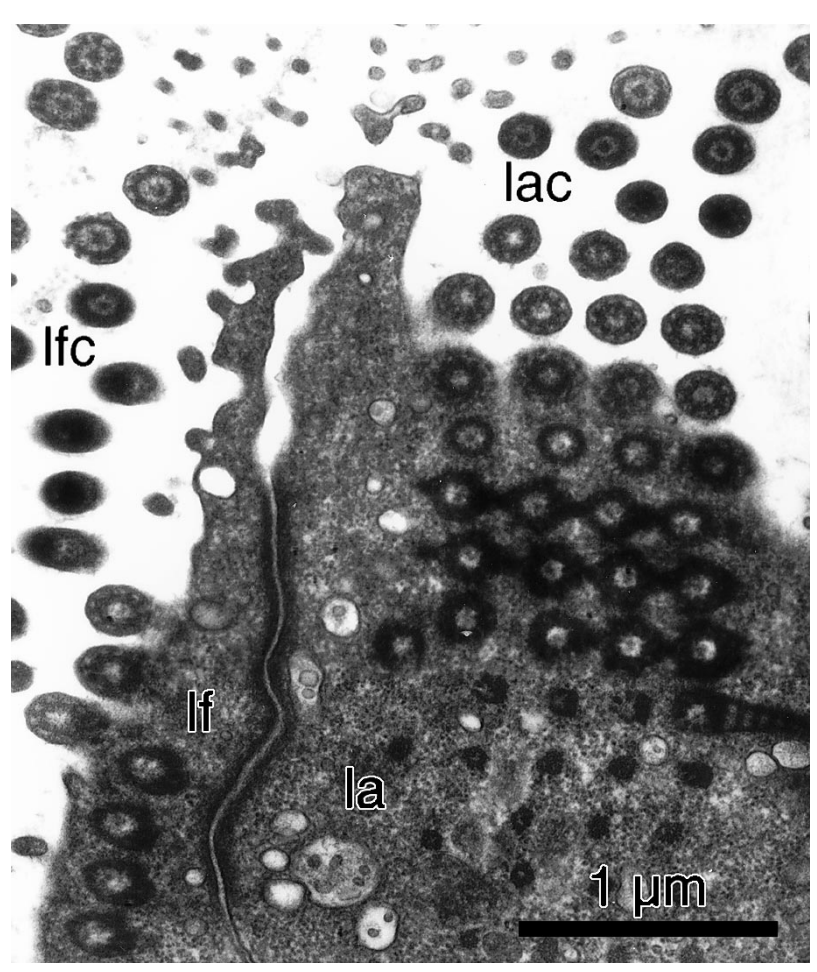

Fig. 2. Spirorbis tridentatus. Grazing section of lateral cells with compound cilia and laterofrontal cells with a row of separate cilia; TEM (la, lateral cell; lac, lateral cilia; lf, laterofrontal cell; lfc, laterofrontal cilia)

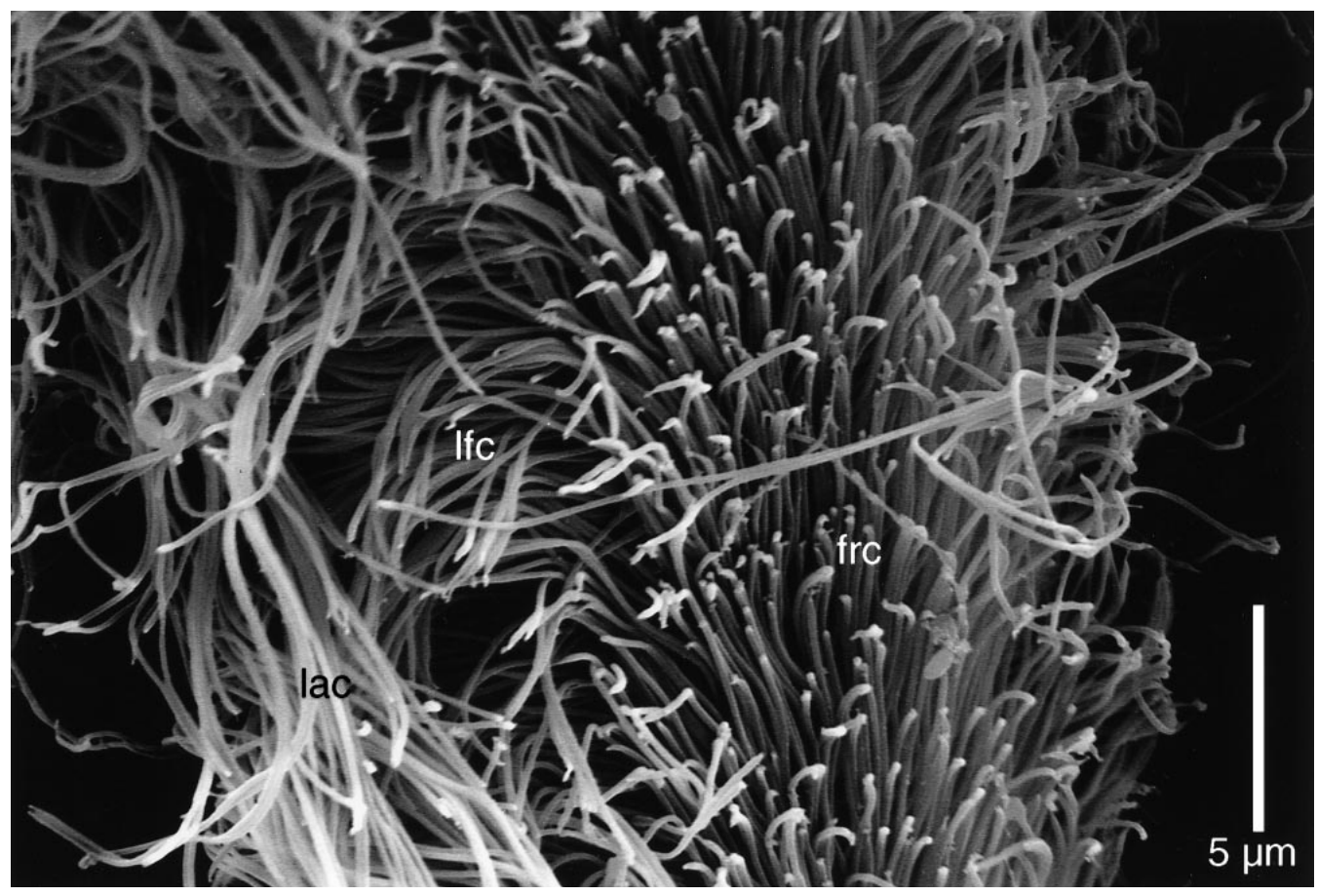

Fig. 3. Spirorbis tridentatus. Frontal side of a pinnule showing lateral compound cilia and separate laterofrontal and frontal cilia; SEM (frc, frontal cilia; lac, lateral cilia; lfc, laterofrontal cilia). Distal end of tentacle upwards 
Fig. 4. Spirorbis tridentatus. Lateral view of a tentacle showing the long compound lateral cilia and an abfrontal ciliary sense organ; SEM (aso, abfrontal sense organ; lac, lateral cilia)

The frontal side of the pinnules (Figs. 1 to 4 ) is covered by 5 rows of ciliated cells, a middle row of frontal cells and paired rows of laterofrontal and lateral cells, which all rest on the basement membrane, attached by conspicuous hemidesmosomes. Their

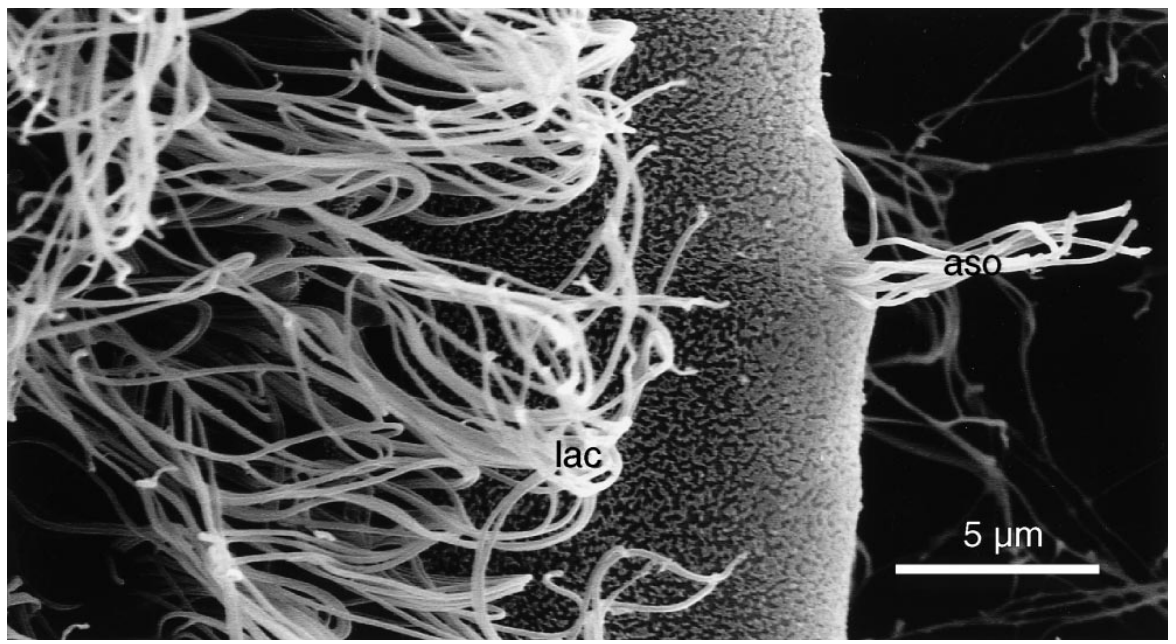
apical side is covered by a well-developed cuticle with slightly branched microvilli having knobbed tips.

The lateral cells are large with big nuclei, and their lateral side is covered by a thin extension of the neighboring lateral cells; they carry a row of about $25 \mu \mathrm{m}$ long compound cilia with long roots, which converge towards the basal part of the cell. Each compound cilium consists of a row of 4 or 5 cilia and the rows are spaced about $0.04 \mu \mathrm{m}$. The lateral compound cilia beat perpendicular to the longitudinal axis of the pinnule. A small longitudinal muscle occupying a groove in the basal side of the cells was observed in some sections.

The laterofrontal cells are narrow, especially in the basal part, and carry 1 row of single cilia, about $12 \mu \mathrm{m}$ long. Both SEM and TEM photos indicate that their beat is almost perpendicular to the longitudinal axis of the pinnule.

The frontal cells are large with a wide apical region and a large nucleus. They carry numerous separate

frontal cilia. A nerve with a small number of axons is situated in a groove in the basal region of the cells. The ciliary roots run almost parallel to the cell surface along the longitudinal axis of the pinnule, and both this and the configuration of the sections of the cilia show that they beat parallel with the longitudinal axis of the pinnule.

\section{Tentacles of Loxosoma pectinaricola}

The ultrastructure of the tentacles of Loxosomella elegans was described by Nielsen \& Rostgaard (1976), and it has been assumed that Loxosoma pectinaricola has a similar tentacle structure. However, the new observations provide information about the ciliary bands of the latter species (Figs. 5 \& 6). The compound lateral cilia are about $25 \mu \mathrm{m}$ long, consist of 2 rows of 4 or 5 cilia each, and are spaced about $0.1 \mu \mathrm{m}$ apart; they beat perpendicular to the longitudinal axis of the tentacle. The band of separate,

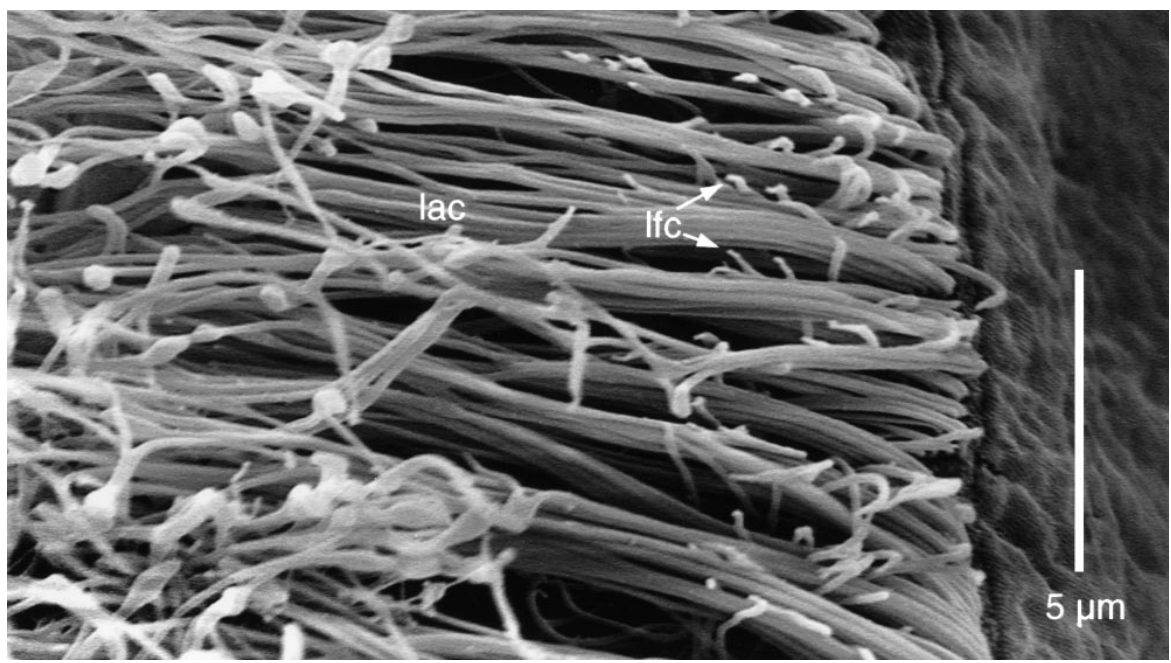
about $10 \mu \mathrm{m}$ long, laterofrontal cilia beat almost obliquely to the longitudinal axis of the tentacle, as indicated by the orientation of their axoneme (Nielsen \& Rostgaard 1976). At the beginning of their effective stroke they protrude between the lateral cilia.

Fig. 5. Loxosoma pectinaricola. Detail of lateral side of tentacle showing tips of laterofrontal cilia protruding between the compound lateral cilia; SEM (lac, lateral cilia; lfc, tips of laterofrontal cilia) 


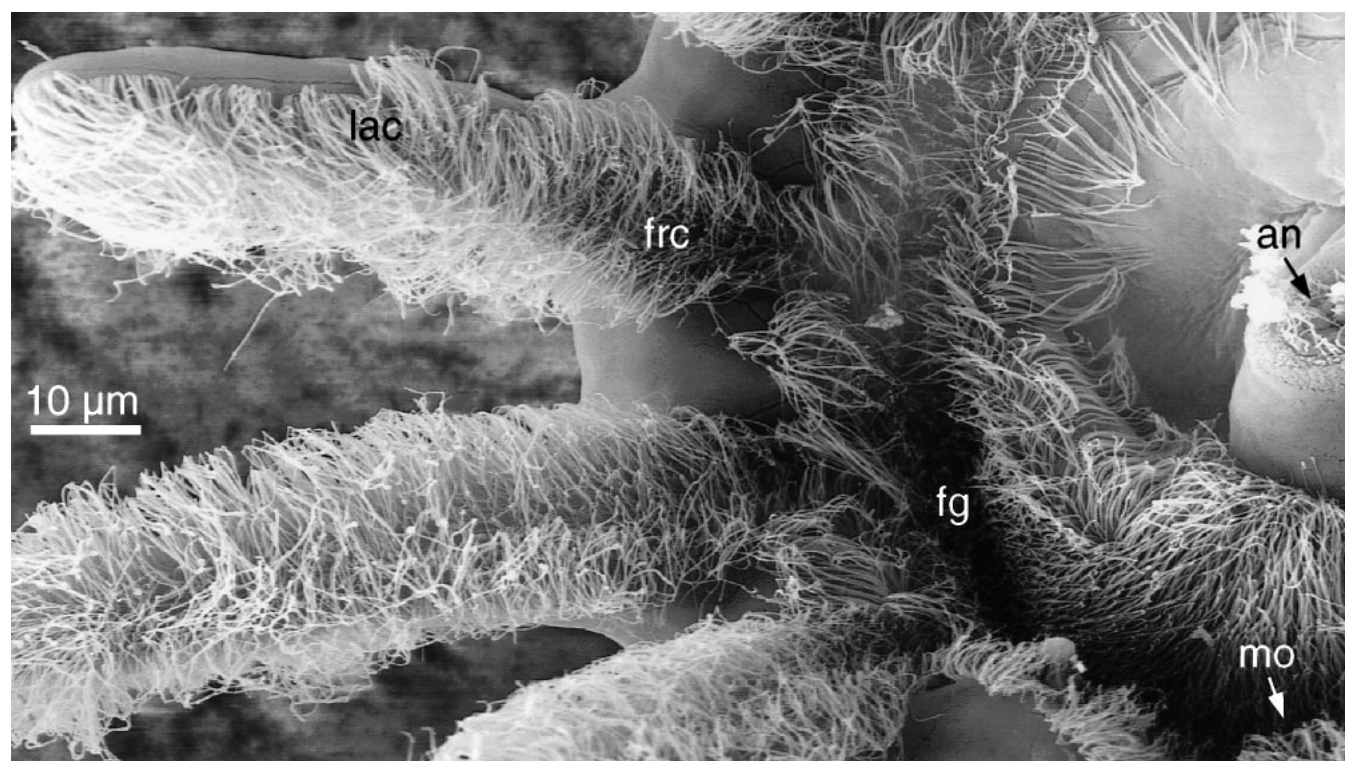

Fig. 6. Loxosoma pectinaricola. Tentacles, food groove and mouth region; SEM (an, anus; frc, frontal cilia; lac, lateral cilia; mo, mouth)

Buccal funnel of Symbion pandora

This is the only described species belonging to the phylum Cycliophora (Funch \& Kristensen 1995, 1997). The feeding stage is about $350 \mu \mathrm{m}$ long with a body consisting of a bell-shaped buccal funnel, an ovoid trunk and a stalk with a disc attaching the animal to setae of the mouthparts (maxillae and maxillipeds) of the host, mainly the Norway lobster Nephrops norvegicus (see Fig. 7). The ciliated buccal funnel tapers toward the trunk region from which it is separated by a constriction ('neck'). The buccal funnel consists of a mouth ring and a mouth cavity with compound cilia. Each compound cilium of the mouth ring is 18 to $22 \mu \mathrm{m}$ long and consists of 9 to 12 cilia in a single radiating row. The mouth ring is about $50 \mu \mathrm{m}$ in diameter and has more than 700 compound cilia. During feeding the mouth ring is everted and the compound cilia form a ring surrounding the mouth opening. If the animal is disturbed, for example by overloading with particles or too high temperature, it retracts the ciliated mouth ring and constricts its periphery by means of apical sphincter muscles.

\section{Video observations}

Low magnification video recordings of particle tracks revealed the global flow fields generated by Spirorbis tridentatus (Fig. 7). The neutrally buoyant particles can here be assumed to follow the fluid motion. In the plane of view shown, fluid is drawn radially in towards the tentacle crown with

velocities that increase from about
Fig. 7. Flow fields generated by Spirorbis tridentatus (seen from above), Loxosoma pectinaricola (in lateral view) and Symbion pandora (seen from behind). The animals are shown as silhouettes; the tube of $S$. tridentatus and the seta of Nephrops norvegicus are shaded. The flow patterns of $S$. tridentatus and $S$. pandora are indicated by dots drawn from video recordings with $0.02 \mathrm{~s}$ intervals, showing particles entering the tentacle crown or the buccal ciliary ring. In $S$. tridentatus, the filtered water leaves the tentacle crown in an obliquely upwards directed flow which is not indicated. The flow pattern of $L$. pectinaricola is hypothetical for stagnant water; the animal is normally situated in the respiration current of the host polychaete 

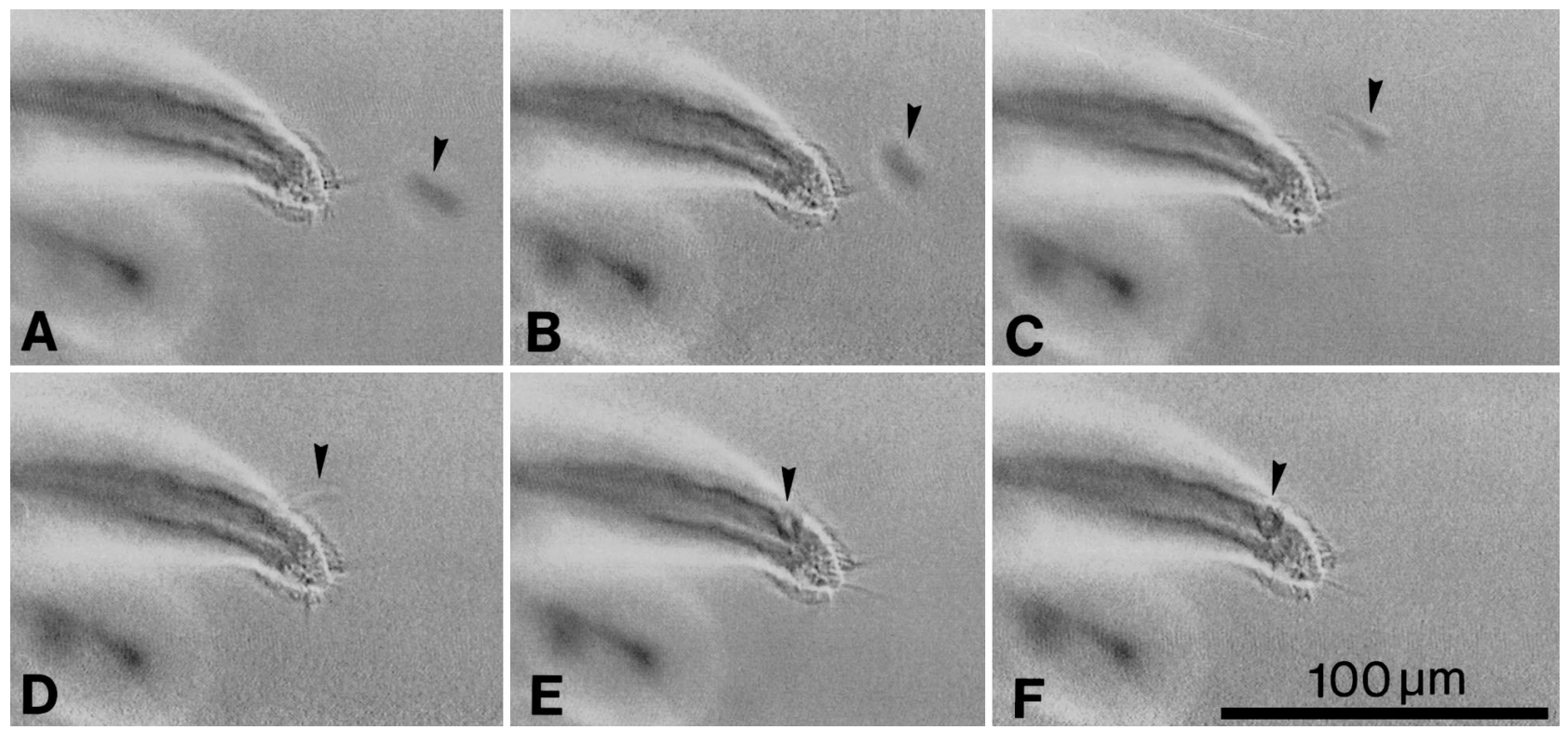

Fig. 8. Spirorbis tridentatus. (A to F) Example of a particle capture. Time interval between successive video frames $=0.02 \mathrm{~s}$

$0.13 \mathrm{~mm} \mathrm{~s}^{-1}$ at a distance of $500 \mu \mathrm{m}$ to about 0.6 to $0.8 \mathrm{~mm} \mathrm{~s}^{-1}$ close to the tentacles. Outward flows were not revealed because they occurred outside the plane of view.

High magnification video observation of feeding in Spirorbis tridentatus and Loxosoma pectinaricola showed that the 2 species use the same basic mechanism for retention of particles, and no metachronal waves were observed.

Examples of particle capture in Spirorbis tridentatus are shown in Figs. 8 \& 9. Particles approaching the pin-
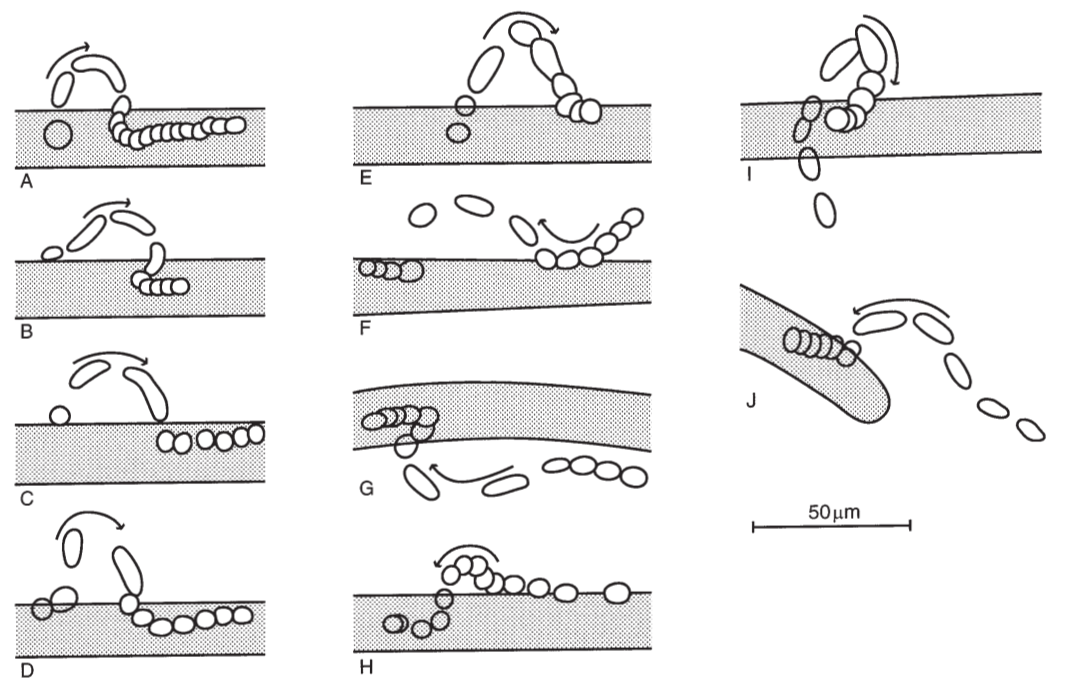

Fig. 9. Spirorbis tridentatus. (A to J) Examples of particle capture. Time interval between successive video frames $=0.02 \mathrm{~s}$. $(\mathrm{J})$ is the example shown in Fig. 8 nules with the upstream water suddenly become accelerated and moved through an arc of over $180^{\circ}$ to be delivered on the frontal side of the pinnule and then transported on the frontal ciliary band toward the mouth. The velocity component of particle motion in the plane recorded (see e.g. Fig. 9J) ranged from upstream values $\left(\sim 20^{\circ} \mathrm{C}\right)$ of about $u_{0}=0.8 \mathrm{~mm} \mathrm{~s}^{-1}$ to maximum values of $0.9-1.2 \mathrm{~mm} \mathrm{~s}^{-1}$ during transfer, to 0.15-0.2 $\mathrm{mm} \mathrm{s}^{-1}$ during transport along frontal ciliary bands. At locations of maximum velocity, particle images were blurred (depth of focus of the microscope was here about $60 \mu \mathrm{m})$ to a distance of 3 to 4 particle diameters $(6 \mu \mathrm{m})$ which also gives estimates of 0.9 to $1.2 \mathrm{~mm}$ $\mathrm{s}^{-1}$. During transfer, particles have a velocity component normal to the plane recorded and, assuming a path forming an angle of $45^{\circ}$ with the normal to the plane, actual maximum velocities may be $\sqrt{2}$ times those observed, or 1.3 to $1.7 \mathrm{~mm} \mathrm{~s}^{-1}$. A comparable estimate, $u_{\text {cap }}=1.6 \mathrm{~mm} \mathrm{~s}^{-1}$, is obtained if the particle goes through an $\operatorname{arc}$ of $150^{\circ}$ with a radius of $25 \mu \mathrm{m}$ during a time interval of 2 video halfframes $=0.04 \mathrm{~s}$. If located at a smaller radius the velocity would be correspondingly smaller. Fig. 9 shows that transfer takes place at a maximum distance (radius) of 15 to $25 \mathrm{~m}$ from the pinnule. An example of particle capture in Loxosoma pectinaricola is 


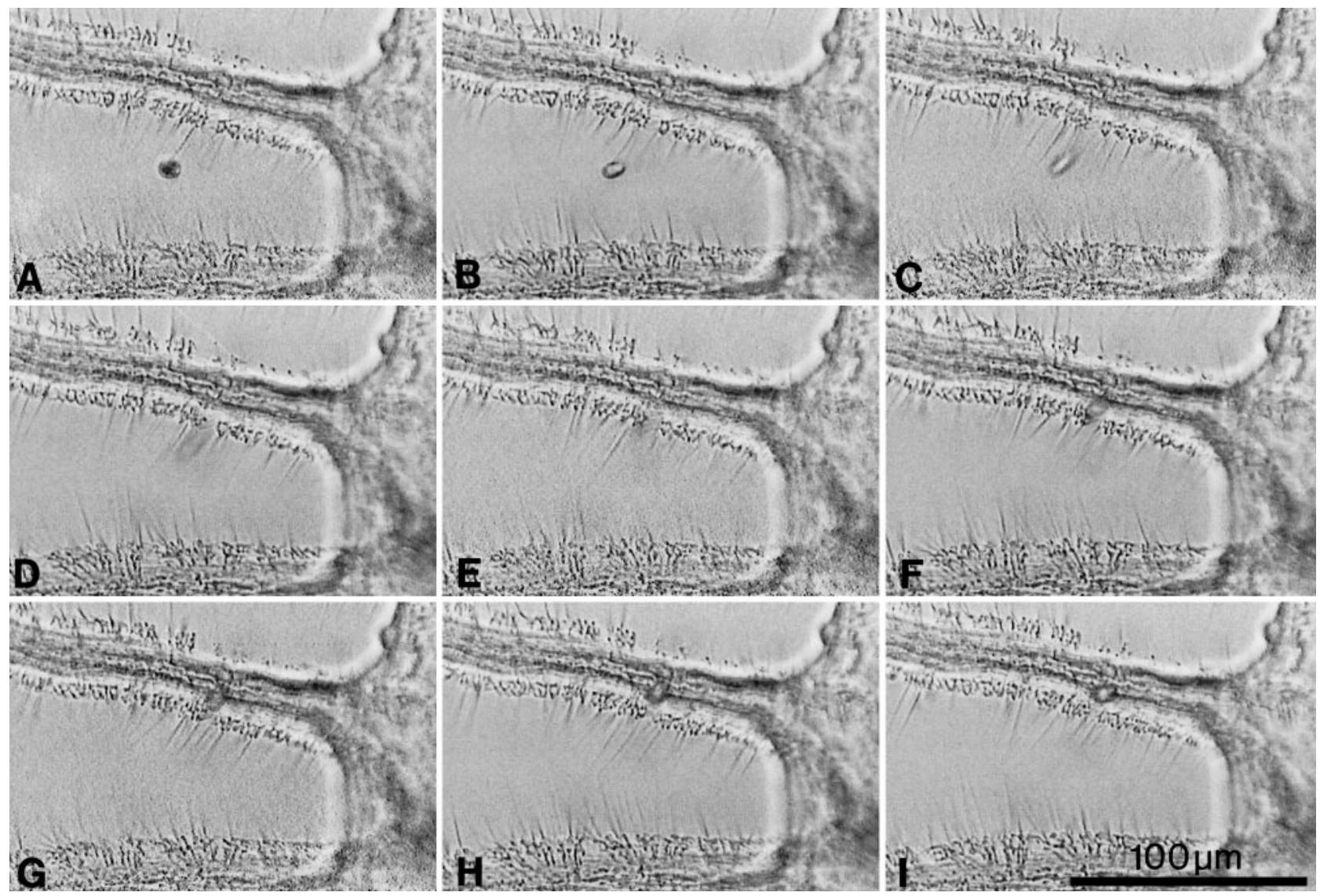

Fig. 10. Loxosoma pectinaricola. (A to I) Example of particle capture. Time interval between successive video frames $=0.02 \mathrm{~s}$

shown in Fig. 10. The first 3 pictures show a particle approaching a tentacle with the upstream water (i.e. perpendicular upwards from the plane of view), whereupon the particle appears to be caught up by the lateral cilia and transferred to the frontal side of the tentacle. The particle tracks are comparable with those obtained for Spirorbis tridentatus (Fig. 9), but the velocities are lower probably due to the considerably lower temperature (about $8^{\circ} \mathrm{C}$ ). Particle tracks indicate an upstream velocity of about $u_{0}=0.3 \mathrm{~mm} \mathrm{~s}^{-1}$ and a maximum capture velocity of about $u_{\text {cap }}=0.8 \mathrm{~mm} \mathrm{~s}^{-1}$. For both species, few particles were observed to pass between tentacles outside the ciliary region.

Low magnification video recordings revealed the global flow fields generated by Symbion pandora (Fig. 7). The compound cilia of the mouth ring create a characteristic system of curved feeding currents approaching the buccal funnel from below with accelerating speeds to obtain maximum values close to the ciliary ring-zone and then disperse outwards in all directions above the animal. High magnification recordings (Fig. 11) show that particles approaching the ciliary zone obtain the highest speed within a dis- tance of about $20 \mu \mathrm{m}$ from the mouth ring, and particles within a distance of about $15 \mu \mathrm{m}$ from the mouth ring may be captured and subsequently swallowed by the animal. During the capture phase the particles are accelerated to a maximum speed of 1.4 to $1.8 \mathrm{~mm} \mathrm{~s}^{-1}$ and simultaneously turned through an arc of near $180^{\circ}$ (Fig. 11). Metachronal waves were not observed. It appears that $S$. pandora share the same basic mechanism for retention of particles with Spirorbis tridentatus and Loxosoma pectinaricola, with the compound cilia on opposite sides of the funnel acting as 'opposed bands'. The function of the compound cilia in the mouth cavity has not been ascertained, but we believe that they transport captured particles towards the gut.

\section{Interpretation of observations}

Our interpretation of the observations of structure and activity of the ciliary bands of serpulid and entoproct tentacles is summarized in Fig. 12, which has been drawn to scale for $6 \mu \mathrm{m}$ diameter particles captured by Loxosoma pectinaricola. The paths and veloc- 


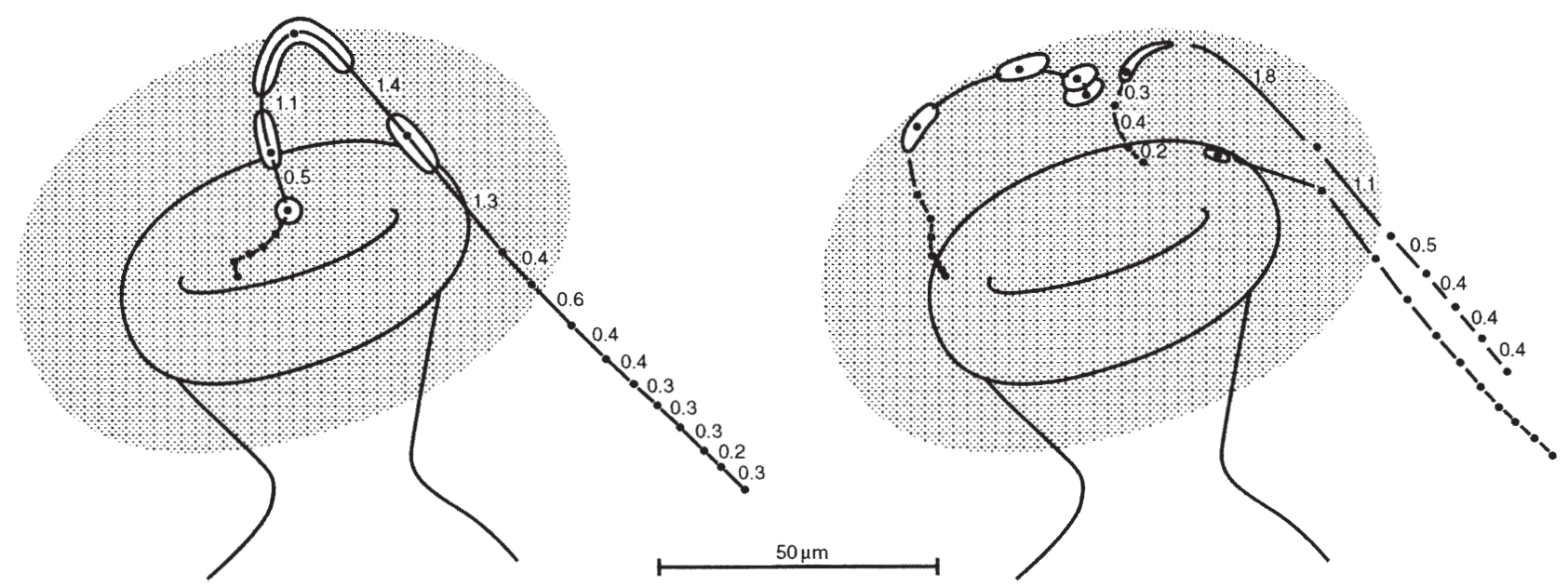

Fig. 11. Symbion pandora. Examples of particle captures; the zone covered by the compound cilia is indicated by shading. The blurred contours of particles during the capture phase are indicated, as well as streamlines and calculated current velocities in the vicinity of the buccal funnel. Time interval between successive video frames $=0.02 \mathrm{~s}$

ities of particles indicate that particles are accelerated with the water that enters the region swept by the compound lateral cilia and then become caught up by 1 and possibly by more of the compound cilia in their power stroke. This element in the process, denoted the 'catch-up principle', accelerates a particle and rapidly moves it in a curved path to the midline at the frontal side of the pinnule. In this phase of the power stroke the particle is thus assumed to be pushed out of the main water current which moves past the tentacle, and as the compound lateral cilia come to rest in their angular motion so does the particle and surrounding fluid. The lateral cilia from the 2 sides of the tentacle apparently prevent escape and move the particle towards the frontal ciliary band. Finally, the frontal cilia carry the particle slowly along the food groove to the mouth. The function of the laterofrontal cilia which, as suggested by the TEM pictures shown in Fig. 4 in Nielsen \& Rostgaard (1976), beat with the effective stroke obliquely towards the frontal midline and protrude between the lateral cilia at the beginning of the effective stroke, has not been ascertained. Two functions may be suggested: a 'cleaning' function, whereby sticky particles are brushed off the lateral cilia, and/or a redirection of the captured particles towards the midline of the frontal band.

The basic principle of particle catch-up as adopted for Loxosoma pectinaricola and Spirorbis tridentatus applies to the cycliophore Symbion pandora, although the structure of 2 opposed ciliary bands is represented by a ring of compound cilia around the mouth and the frontal ciliary band by a ciliated mouth cavity.

We further interpret the reports on the function of the ciliary bands of larvae of annelids, molluscs and entoprocts and of adult rotifers in a similar way
(Fig. 13). The differences between these ciliary bands and those of the adults studied here appear small. The entoproct tentacles, the polychaete pinnules and the mouth ring of Symbion pandora have opposing bands of compound cilia of equal lengths, whereas the prototroch cilia of mollusc and annelid larvae are much longer than those of the metatroch; this appears to be related to different life styles, with the prototroch being used for locomotion in the larvae and some of the rotifers. We see no differences in the basic function of

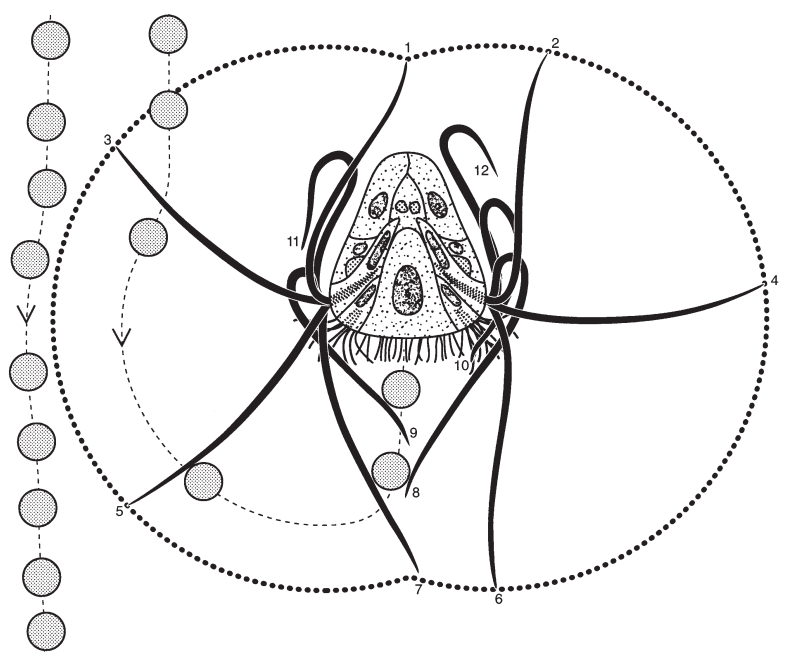

Fig. 12. Loxosoma pectinaricola. Cross section of a tentacle showing how the compound lateral cilia are assumed to catch up a particle which then becomes accelerated and transferred to the frontal side of the tentacle. The shape of the beat of the lateral compound cilia is drawn on the basis of Nielsen \& Rostgaard (1976, Fig. 20) and SEM observations. The dotted line indicates the zone covered by the lateral cilia 


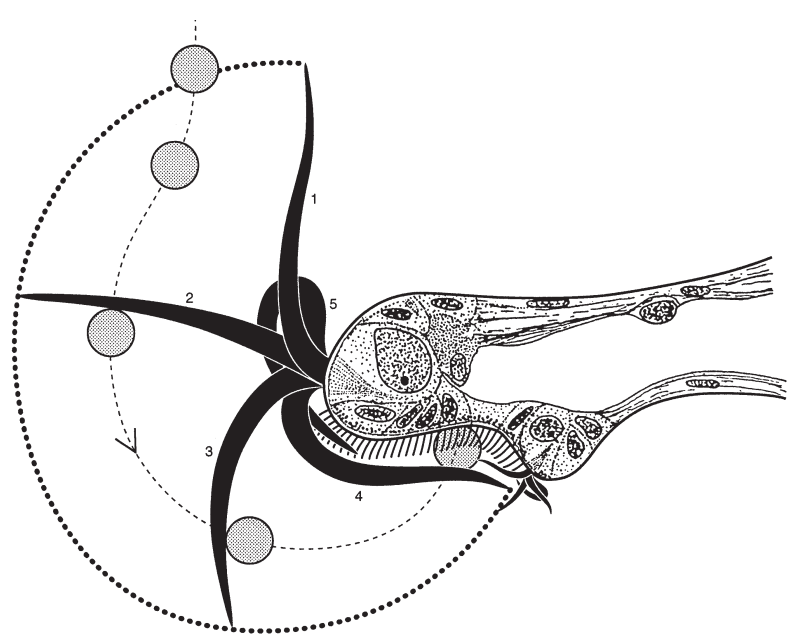

Fig. 13. Cross section of the velar edge of a gastropod (partly based on Crepidula fornicata, see Werner 1955) showing our interpretation of the function of the ciliary bands

the 2 types in regard to particle capture. We have no explanation for the significance of the presence versus absence of the metachronal waves in the ciliary bands. However, differences in cilia length and structure of opposing bands affect retention efficiency as discussed in a later section.

The present interpretation of observations concerns the capture mechanism in regard to cilia systems on 1 tentacle or 1 isolated organism. Opposing bands of cilia on adjacent tentacles (e.g. in Sabella penicillus) are likely to also affect the retention efficiency as discussed in a later section.

\section{Fluid mechanical considerations}

The catch-up elements of the capture process, as described in the above section, have also been suggested by Strathmann \& Leise (1979), who measured both ciliary and particle velocities to supply observational substantiation of the catch-up hypothesis as their best guess. The present paper adds evidence that the 'catch-up hypothesis' is physically plausible. In this section the adopted hypothesis is examined in light of the available observations and simple considerations from fluid mechanics. For a complete picture we should know the kinematics of particles, cilia and fluid. In effect, observations provide only information on path and velocity of particles. The motion of cilia and fluid must therefore be inferred from theory and available descriptions of other species. The key issues for the hypothesis are: particles should enter the interciliary region, move with a velocity less than that of the cilia during their active stroke and reside in the region long enough to be intercepted by some cilia.
Velocities of particles, cilia and water

As seen also in the present study, particles to be captured arrive usually within the interciliary region of the preoral band, and particles near the cilia tips are more frequently lost than particles closer to the cilium root (Strathmann et al. 1972, Strathmann \& Leise 1979, Gallager 1988). Also, particles that are captured from the interciliary region have been observed to rotate, ascribed to the recovery stroke (Gallager 1988). In the present study, captured particles were observed to 'rotate' and the simple explanation of such motion is that the particles move in an arc similar to the arc swept by the cilia in their effective strokes.

Mayer (1994) observed that captured particles had trajectories passing close to the cilia tips and that very few particles passed through the about $40 \mu \mathrm{m}$ of free space between opposite compound lateral cilia tips in the polychaete Sabella penicillus, suggesting that particles were preferentially drawn with the fluid into the interciliary region or to the vicinity of cilia tips. This suggestion is qualitatively supported by the computer simulations by Nielsen et al. (1993) for flow driven by the lateral cilia of a single filament of Mytilus edulis.

The following considerations are therefore focused on velocities in the interciliary region, and typical dimensions are taken from the present observations on Spirorbis tridentatus. First, the tip velocity $\left(u_{\text {tip }}\right)$ of an active cilium of length $L$ turning through an arc of $\theta$ degrees during a time interval of $T_{\mathrm{a}}$ may be approximately estimated from

$$
u_{\text {tip }}=(\theta / 360) 2 \pi L / T_{\mathrm{a}}=\omega L
$$

where $\omega$ equals the mean angular velocity of the cilia. According to Sleigh \& Holwill (1969) the duration of an effective stroke $T_{\mathrm{a}}$ is generally about 0.2 to $0.3 T_{\text {, }}$ where $T=1 / f$ denotes the full period of a beat, $f$ being the frequency. In the idealized motion of compound lateral cilia (clc) the effective stroke is considered as a rotation of a rigid cylindrical rod about one of its ends with constant angular speed. This is a simplication according to, e.g., Sleigh \& Holwill (1969, their Figs. 1, 2 \& 3).

Further, the mean upstream velocity (without correction for a minor negative effect of the recovery stroke) is in the present work approximately estimated as half the tip velocity (= mean velocity of cilium during active stroke) multiplied by the ratio between duration of active to complete stroke

$$
u_{0}=0.5 u_{\text {tip }}\left(T_{\mathrm{a}} / T\right)
$$

This estimate is clearly approximate, and it may be expected to depend on parameters such as spacing between pinnules and length of cilia. 
The fluid velocity in the interciliary region may be estimated to be a factor $\beta=1.5$ to 2 smaller than the local velocity of a cilium in its active stroke,

$$
u_{\text {fluid }} \approx u_{\text {cilium }} / \beta
$$

where the value of $\beta$ is from the experimental data of Emlet (1990) for $5.5 \mu \mathrm{m}$ diameter particles (Isochrysis galbana).

As an alternative, the fluid velocity may be estimated from simple considerations of mass conservation, i.e. the product of mean velocity and flow area being constant. For the case of parallel pinnules of diameter $d_{\mathrm{t}}$ spaced a distance $l_{\mathrm{s}}$ apart, assuming the velocity to increase linearly from 0 at the pinnule to $u_{\max }$ at the tip of clc of length $L$ and remain at this value between opposing cilia tips, continuity gives the estimate

$$
u_{\max }=u_{0} l_{\mathrm{s}} /\left(l_{\mathrm{s}}-d_{\mathrm{t}}-L\right)
$$

Actually, somewhat higher fluid velocities would prevail near the tip if back-flow occurred near the root due to the recovery beat, and if fluid were preferentially drawn into the interciliary region as pointed out above; hence Eq. (4) may give an underestimate.

For Spirorbis tridentatus $\left(\theta=180^{\circ}, L=25 \mu \mathrm{m}, T_{\mathrm{a}} / T=\right.$ $0.3, f=15 \mathrm{~Hz}$ ), we calculate $u_{\text {tip }} \approx 3.9 \mathrm{~mm} \mathrm{~s}^{-1}$ from Eq. (1), estimate $u_{0} \approx 0.6 \mathrm{~mm} \mathrm{~s}^{-1}$ from Eq. (2) and $u_{\text {fluid }} \approx$ 1.2 to $2 \mathrm{~mm} \mathrm{~s}^{-1}$ from Eq. (3) in the range of observed particles, 15 to $25 \mu \mathrm{m}$ from the root of the lateral cilia. According to Eq. (4), for $l_{\mathrm{s}}=100 \mu \mathrm{m}, d_{\mathrm{t}}=20 \mu \mathrm{m}$ and $L=25 \mu \mathrm{m}$, the fluid velocity would not be less than $1.45 \mathrm{~mm} \mathrm{~s}^{-1}$ near the tip. The estimates are in reasonable agreement with observed particle velocities both upstream and in the interciliary region, hence implying that particles appear to follow the fluid. The tip speed of lateral cilia exceeds observed particle velocity by a factor of about 2; hence particle interception would seem likely. Such catch-up could cause a slowing down of the cilia as suggested in the previous section.

In the next 3 sections we address 4 questions: (1) Is the probability of interception high enough to be likely? (2) Does interception imply contact or do lateral cilia push fluid (and particle) ahead? (3) Does the viscous drag load from an intercepted particle represent a significant extra load for the compound lateral cilia compared to the viscous drag load from the fluid alone, thus reducing the cilia speed? and (4) What is the deflection of cilia due to load from fluid, and during capture of a particle?

\section{Particle interception}

Although the duration of active stroke (about $0.02 \mathrm{~s}$ ) is about half that of a particle passing the interciliary region (about $0.04 \mathrm{~s}$ ), interception will rely on proper timing of the 2 events locally. Being spaced at about $0.4 \mu \mathrm{m}$ there would be potentially 15 compound lateral cilia that could intercept a $6 \mu \mathrm{m}$ particle if they were in the right phase of beat. No metachronal waves have been observed, and we shall assume that the lateral cilia beat in random phases. The sketches in Fig. 14A,B show, for $T_{\mathrm{a}} / T=0.3$, cilia in metachrony and in random phase, respectively; the latter was drawn using a random number generator. For the case of metachrony, at any one time, only about $30 \%$ of the interciliary region is being swept by cilia in their active stroke. At random phase, however, all of the space is covered provided adjacent cilia in their active stroke can entrain the water to a sufficient velocity between them, as depicted in Fig. 14C and explained below. This suggests the functionality of random phase beating.

Suppose we are given $n$ compound lateral cilia of equidistant spacing $\Delta L(=0.4 \mu \mathrm{m})$ along a pinnule, beating in random phase. Defining a phase interval, $\Delta T$, of the full period of beat, $T$, then the fraction $n(\Delta T / T)$ of the cilia would be 'in phase' in this sense, and their average spacing would be simply $\Delta L(T / \Delta T)$. Other clc would be out of this phase. Choosing $\Delta T / T=0.1$, which is about half of the active stroke, and $n=15$, the fraction of cilia in phase would be $15 \times$ $0.1 \approx 1.5$, and the average spacing between cilia in phase would be 0.4/0.1 = $4 \mu \mathrm{m}$. Either statement suggests that one might expect to find between 1 and 2 of the 15 cilia in the middle of the active stroke, indicating a high probability of interception.

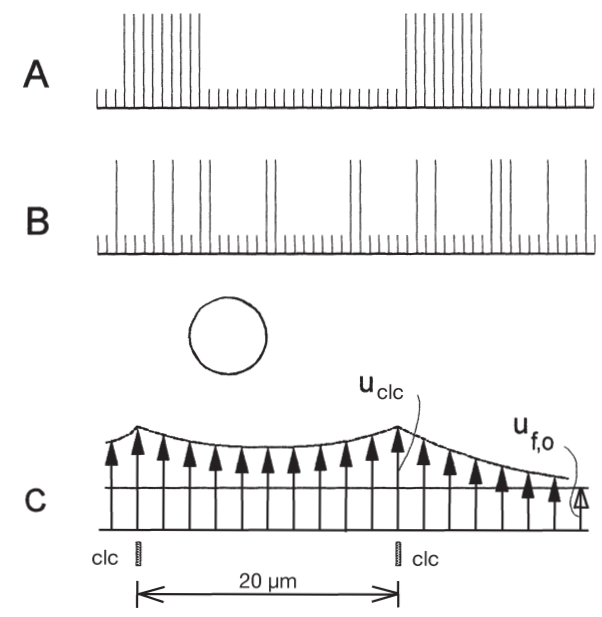

Fig. 14. Schematic of compound lateral cilia (clc) beating in metachrony (A) and in random phase (B) (spacing and length not to scale). For the latter, (C) shows schematically the expected distribution of fluid velocity between and near $2 \mathrm{clc}$, $20 \mu \mathrm{m}$ apart and closely in phase during active stroke; $u_{\mathrm{clc}}=$ $3.9 \mathrm{~mm} \mathrm{~s}^{-1}$; fluid velocity far from clc, $u_{\mathrm{f}, 0}=1.6 \mathrm{~mm} \mathrm{~s}^{-1}$. Particle drawn to scale, diameter $=6 \mu \mathrm{m}$ (see section 'Particle interception' for details) 
The foregoing example suggests that a particle may be intercepted by a single cilium or more likely by 2 cilia. Let us consider the case of 2 cilia that are closely in phase, say within $1 / 10$ of the active stroke; hence $\Delta T / T=0.02$ and the expected spacing would be $\Delta L$ $(T / \Delta T)=0.4 / 0.02=20 \mu \mathrm{m}$. Even at this large value of spacing-to-diameter of 2 cylinders ( $\mathrm{s} / \mathrm{d}=20 / 0.4=50$ ) there will be a considerable resistance to fluid passing in between the 2 cilia. Thus, the undisturbed relative velocity $\Delta u=u_{\text {clc }}-u_{\mathrm{f}}$ (at the tip of clc about $3.9-1.6=$ $2.3 \mathrm{~mm} \mathrm{~s}^{-1}$ ) prevailing far from the clc pair will be reduced in the space between them, on average, to the fraction called the leakiness. From the study by Cheer \& Koehl (1987) this fraction, at a Reynolds number of about $\operatorname{Re}_{\mathrm{r}}=\Delta u d_{\text {clc }} / v \approx 10^{-4}$ to $10^{-3}$, will be of the order of 0.2 , hence between the pair of clc, $\Delta u=0.2 \times 2.3 \approx$ $0.5 \mathrm{~mm} \mathrm{~s}^{-1}$ and $u_{\mathrm{f}} \approx 3.4 \mathrm{~mm} \mathrm{~s}^{-1}$, so the fluid velocity here is only slightly smaller than that of the clc (Fig. 14). Clearly, the estimate would yield half these values if the event were to take place not at the tip but halfway between tip and root of the clc.

In effect, the pair of cilia 'pushes' fluid ahead in some region which extends many cilia-diameters in all directions. A particle in this fluid will of course be accelerated with the fluid, not representing any added load. However, once caught up by the faster moving cilia, hence being pushed relative to the fluid, there would be added resistance. Also, if the motion of clc is halted the fluid ahead of it - including a transported particle — is also halted.

\section{Mechanical load on cilia and their deflection}

The mechanical load on the clc may be expressed, as in structural mechanics for a cantilever beam, in terms of the shear force at the root, $F$, the bending moment at the root, $M$, and the deflection of the tip, $Y_{\text {tip. }}$. As indicated in Fig. 15 we consider the phase of active beating with cilia perpendicular to the filament and main flow, yielding the maximal loads, either from an intercepted particle or from the relative fluid motion.

First, for a spherical particle of diameter $D$ resting at the tip of clc and subject to a relative fluid velocity $\Delta u$, the viscous drag force may be calculated according to the Stokes law for creeping flow,

$$
F_{\mathrm{D}}=3 \pi \mu D \Delta u
$$

where $\mu$ is the dynamic viscosity $\left(1.07 \times 10^{-3} \mathrm{~N} \mathrm{~s} \mathrm{~m}^{-2}\right.$ at $20^{\circ} \mathrm{C}$ ). For simplicity we consider the reference case of $D=6 \mu \mathrm{m}$ and $\Delta u=1 \mathrm{~mm} \mathrm{~s}^{-1}$, yielding $F_{\mathrm{D}}=0.6 \times 10^{-10} \mathrm{~N}$.

Consider next the viscous drag force per unit length, $F^{\prime}$, acting on a compound lateral cilium due to a relative fluid velocity, $\Delta u$, perpendicular to the cilium. Among the several ways of estimating this force (see Appendix 1) we consider the approximate solution, Eq. (A4), for the infinitely long cylinder at small values of the Reynolds number, $R e=\rho d \Delta u / \mu$ (Van Dyke 1964, p. 164; see also Happel \& Brenner 1965, p. 48)

$$
F^{\prime}=8 \pi \mu \Delta u /[2 \ln (8 / \operatorname{Re})-0.154]
$$

Employing $\Delta u=1 \mathrm{~mm} \mathrm{~s}^{-1}$ and $d=0.4 \mu \mathrm{m}$ (equivalent to 2 rows of cilia) yields $\mathrm{Re} \approx 4 \times 10^{-4}$ and $F^{\prime}=1.4 \times 10^{-6} \mathrm{~N}$ $\mathrm{m}^{-1}$. Using this value at the tip and assuming the relative velocity to decrease linearly from $\Delta u=1 \mathrm{~mm} \mathrm{~s}^{-1}$ at the tip to 0 at the root of the clc, implying a similar linear variation of the force per unit length, the total viscous force acting on the $L=25 \mu \mathrm{m}$ long cilium becomes $F=F^{\prime} L / 2=0.17 \times 10^{-10} \mathrm{~N}$. This value is about $25 \%$ of $F_{\mathrm{D}}$ due to an intercepted particle, but use of other approximations from Appendix 1 would give higher values of $F^{\prime}$, particularly for cilia in phase and considered to be an array of parallel cylinders; hence it is fair to conclude that the 2 different total loads are of the same order of magnitude, although their distributions along the cilia are different.

The computed total load forces $F$ and $F_{\mathrm{D}}$ also represent the shear force acting at the root of the compound cilia at local equilibrium. Using standard relations from the mechanics of a simple elastic beam (see e.g. Timoshenko \& Goodier 1951), the root moment and tip deflection are readily calculated for the 2 cases, yielding the equations and results given in Table 1, where the flexual rigidity of compound cilia is taken to be $S \approx 10^{-17} \mathrm{~N} \mathrm{~m}^{2}$ (Baba 1972; gives for different sizes of compound cilia the values, 3 to $13 \times 10^{-18} \mathrm{~N} \mathrm{~m}^{2}$ ).

The expressions in Table 1 show that if the total force load (equal to the root shear force $F$ ) is assumed to be

Table 1. Summary of representative estimates of mechanical load on single, $L=25 \mu \mathrm{m}$ long compound lateral cilium (composed of 2 rows of cilia) due to viscous drag from, respectively, a relative fluid velocity of $1 \mathrm{~mm} \mathrm{~s}^{-1}$ at the tip (decreasing to 0 at root of cilium) and a $6 \mu \mathrm{m}$ spherical particle at the tip subject to a fluid velocity of $1 \mathrm{~mm} \mathrm{~s}^{-1}$ ( $F^{\prime}$, drag force per unit length of cilium at tip

\begin{tabular}{|c|c|c|c|c|}
\hline \multirow[b]{2}{*}{ Shear force $F$} & \multicolumn{2}{|c|}{ Load from fluid } & \multicolumn{2}{|c|}{ Load from drag on $6 \mu \mathrm{m}$ particle at tip } \\
\hline & $F^{\prime} L / 2$ & $0.17 \times 10^{-10} \mathrm{~N}$ & $F_{\mathrm{D}}$ & $0.6 \times 10^{-10} \mathrm{~N}$ \\
\hline Root moment $M$ & $F^{\prime} L^{2} / 3$ & $0.29 \times 10^{-16} \mathrm{~N} \mathrm{~m}$ & $F_{\mathrm{D}} L$ & $1.5 \times 10^{-16} \mathrm{~N} \mathrm{~m}$ \\
\hline Tip deflection $Y_{\text {tip }}$ & $(11 / 120) F^{\prime} L^{4} / S$ & $0.005 \mu \mathrm{m}$ & $F_{\mathrm{D}} L^{3} /(3 S)$ & $0.03 \mu \mathrm{m}$ \\
\hline
\end{tabular}
due to viscous flow; $F_{\mathrm{D}}$, Stokesian drag force on sphere acting at tip; $S$, flexual rigidity of compound cilia) 
the same for the 2 loads, then the root moment $M$ and tip deflection $Y_{\text {tip }}$ for the distributed load of fluid drag is only a factor $2 / 3$ and $11 / 20$, respectively, times that due to tip load of drag on an intercepted particle. For the stationary laterofrontal cilia in cyphonautes, Strathmann \& McEdward (1986) estimated the tip deflection for a $20 \mu \mathrm{m}$ long cilium encountered by a $5 \mu \mathrm{m}$ diameter particle with a velocity of $1 \mathrm{~mm} \mathrm{~s}^{-1}$ to be $Y_{\text {tip }}=0.45$ or $0.67 \mu \mathrm{m}$ (after correction for miscalculation) depending of flexural stiffness.

While the deflection due to elastic bending is insignificant in all cases (cilia are known to autonomously [actively] bend much more), the analysis shows that root shear and root moment about double and triple, respectively. The significant increase in root moment in particular may be expected to slow down the ciliary motion, since the root moment is perceived to drive the active stroke.

\section{Ciliary downstream collecting in other invertebrates}

Structure of other downstream collecting systems

Planktotrophic trochophora and veliger larvae of annelids, molluscs and entoprocts and a few adult rotifers have downstream collecting ciliary systems. These larvae have a preoral prototroch of long compound cilia, a postoral metatroch of shorter compound cilia, and an adoral ciliary zone of separate cilia (the food groove); these ciliary bands are carried by multiciliate cells (Nielsen 1987; only the larva of the polychaete Owenia has separate cilia and monociliate cells, see Emlet \& Strathmann 1994). A very similar system is found in the rotifers, where the prototroch is usually called trochus and the metatroch cingulum (Strathmann et al. 1972, Nielsen 1987). The prototroch usually consists of 1 row of compound cilia, but 2 rows of cells with compound cilia are found in some annelid and mollusc larvae (for example Polygordius, see Hatschek 1878, and Ostrea, see Erdmann 1935, Waller 1981). All the larvae appear to have a narrow band of single, rather short pretrochal cilia on the apical side of the prototroch; the function of this band is unknown. Both the swimming larvae and the rotifers show conspicuous metachronism in the prototroch, and this has given the popular name 'wheel animalcules' to the rotifers.

The structure of the ciliary bands of polychaete trochophora larvae has been studied in a number of species. Planktotrophic filter-feeding larvae with prototroch and metatroch are known from the families Opheliidae (Armandia, Hermans 1978), Capitellidae (Mediomastus, Hansen 1993), Oweniidae (Owenia, Emlet \& Strathmann 1994), Serpulidae (Spirobranchus, Serpula, Pomatoceros, Galeolaria, Segrove 1941, Strath-

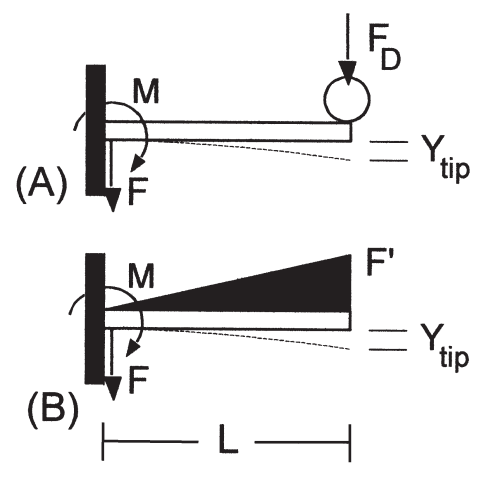

Fig. 15. Compound lateral cilia subject to load from (A) drag force $\left(F_{\mathrm{D}}\right)$ on intercepted particle, and $(\mathrm{B})$ drag forces $\left(F^{\prime}\right.$ per unit length) due to linearly increasing fluid velocity over length $(L)$ from root to cilium tip $(F$, total shear force at root; $M$, bending moment at root; $Y_{\text {tip }}$, deflection of cilium tip)

mann et al. 1972, Grant 1981, Nielsen 1987), and Polygordiidae (Polygordius, Woltereck 1902). The echiurids are now regarded as specialized annelids by some authors (Nielsen 1995, McHugh 1997), and both Echiurus and Urechis have planktotrophic trochophores (Balzer 1917, Newby 1940). Some amphinomid larvae (rostraria larvae, Jägersten 1972) and magelonid larvae (Wilson 1982) have the prototroch drawn out on a pair of long tentacles, which thus resemble the tentacles described above, but detailed studies are lacking. The presence of a ciliary band corresponding to the laterofrontal cilia of the tentacles of entoprocts and serpulids described above has not been discussed before, but a row of single cilia in the same position is reported from larvae of the polychaete Spirobranchus by Lacalli (1984).

The structure of the velum of gastropod and bivalve larvae is well known through several studies, for example the gastropods Crepidula (Werner 1955), and Mitrella (Nielsen 1987) and the bivalves Ostrea (Waller 1981), Barnea (Nielsen 1987), Mercenaria (Gallager 1988) and Codakia (Gros et al. 1997). Most species have early, non-feeding, trochophora-like stages with a large prototroch, but later on develop into feeding veligers with an adoral ciliary zone and metatroch (Gros et al. 1997). Some SEM observations (see for example Fig. 16) indicate the presence of a row of cells with laterofrontal cilia along the oral side of the prototroch; these cilia extend in the beginning of their effective stroke between the basal parts of the prototroch cilia, just as in the entoproct tentacle.

Entoproct larvae are almost all planktotrophic and have the usual trochophore-type ciliary bands described above for polychaetes (Nielsen 1987); there is usually only 1 row of prototrochal cells, but Malakhov 


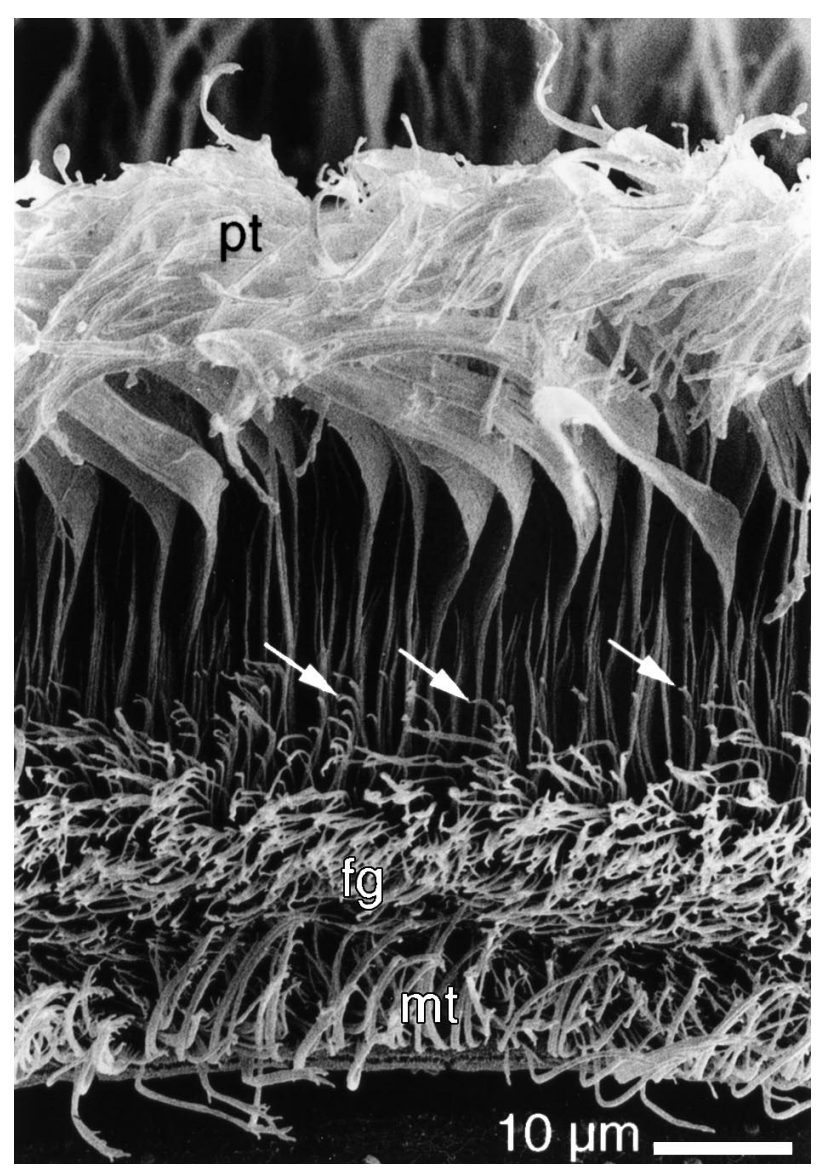

Fig. 16. Barnea candida. SEM of velar edge of bivalve larva with very large compound cilia in the prototroch (pt), smaller compound cilia in the metatroch (mt) and separate cilia in the food groove (fg), where the separate cilia closest to the prototroch appear to extend into the narrow spaces between the prototroch cilia (arrows)

(1990) reported 2 rows in the larva of Barentsia discreta. Downstream collecting has been observed in a number of larvae, but detailed observations are lacking.

A few pelagic and sessile rotifers have a ciliary feeding apparatus resembling that of the trochophores (Philodina and Rotaria: Strathmann et al. 1972, Melone \& Ricci 1995; Conochilus: Nielsen 1987), and rotifers may perhaps be interpreted as 'neotenous' trochophores.

All these observations indicate that the opposed ciliary bands of trochophores and rotifers have the same structure and function as those of entoproct and serpulid tentacles and of Symbion pandora described above, the only obvious differences being the size divergence between the 2 opposed bands and the absence of metachronism in the ciliary bands of the organisms studied here. Strathmann et al. (1972) pointed out that only planktotrophic trochophores have a metatroch and has suggested that the meta- troch is necessary for the function of the 2 opposed ciliary bands. This is in complete agreement with our above interpretation.

\section{Other data related to particle capture}

The examples given below all seem to be in agreement with the ciliary 'catch-up principle' because particles are accelerated in the ciliary region to higher velocities $\left(u_{\mathrm{p}}\right)$ relative to the upstream velocity $\left(u_{0}\right)$ of water in which they are otherwise entrained, and because $u_{\mathrm{p}}$ is lower than the local unrestrained cilia velocity $\left(u_{\text {clc }}\right)$. These conditions suggest a high probability of particle catch-up, possibly slowing down the cilia due to restraining drag from the particle being intercepted.

Movements of the compound cilia on the gills of the polychaete Sabellaria sp. have been studied by Sleigh \& Holwill (1969). During the power stroke the $32 \mu \mathrm{m}$ long compound cilium moves through an arc of $150^{\circ}$, the beat frequency is $16.6 \mathrm{~Hz}$ at $20^{\circ} \mathrm{C}$, the effective stroke is completed within $T_{\mathrm{a}}=0.024 \mathrm{~s}$, and the whole cycle of beating lasts $T=0.06 \mathrm{~s}$. Using Eq. (1) the tip velocity can thus be estimated to be $u_{\text {tip }}=(150 / 360) \times$ $2 \pi \times 0.032 / 0.024=3.5 \mathrm{~mm} \mathrm{~s}^{-1}$, while using Eq. (2) the upstream velocity of water and suspended particles (which are 'locked up' in the surrounding water due to negligible inertia) may be estimated to be $u_{0}=0.7 \mathrm{~mm}$ $\mathrm{s}^{-1}$. Particle velocities in the ciliary region were not measured by Sleigh \& Holwill.

In the polychaete Sabella penicillus, which has compound cilia of approximately $20 \mu \mathrm{m}$ in length, the upstream velocity was experimentally measured by Mayer (1994) to be $u_{0}=1.0 \mathrm{~mm} \mathrm{~s}^{-1}$, while the maximum particle velocity during the capture phase observed near the tip was $u_{\mathrm{p}}=1.7 \mathrm{~mm} \mathrm{~s}^{-1}$. According to Eq. (1), assuming $T_{\mathrm{a}}=0.015$ to $0.024 \mathrm{~s}$, the tip velocity in $S$. penicillus is about $u_{\text {tip }}=2.2$ to $3.5 \mathrm{~mm} \mathrm{~s}^{-1}>u_{\mathrm{p}}$.

Gallager (1988) used high speed video microscopy to study particle capture in 10-d-old bivalve (Mercenaria) larvae with $45 \mu \mathrm{m}$ long preoral cilia beating with $20 \mathrm{~Hz}$ and with a duration of the effective stroke $T_{\mathrm{a}}=0.015 \mathrm{~s}$. It was found that the particle velocity increases from $u_{\mathrm{p}}=1.5 \mathrm{~mm} \mathrm{~s}^{-1}$ about $15 \mu \mathrm{m}$ above the cilium base to $u_{\mathrm{p}}=3.3 \mathrm{~mm} \mathrm{~s}^{-1}$ at the cilium tip. Using Eq. (1) it can be estimated that the unrestrained tip velocity is $u_{\text {tip }}=$ $7.9 \mathrm{~mm} \mathrm{~s}^{-1}$, or more than twice the restrained velocity during the capture phase, while the upstream velocity using Eq. (2) is estimated to be $u_{0}=1.2 \mathrm{~mm} \mathrm{~s}^{-1}$.

Emlet \& Strathmann (1994) made a comparison of reported maximum speeds of $5.5 \mu \mathrm{m}$ diameter particles through the ciliary region in larvae with preoral cilia of different lengths, ranging between about 20 and $130 \mu \mathrm{m}$. From the near linear relation between particle 
speed and cilium length it is found that a 30 and $100 \mu \mathrm{m}$ long cilium correlates with $u_{\mathrm{p}} \approx 2$ and $7 \mathrm{~mm} \mathrm{~s}^{-1}$, respectively. Using Eq. (1) the ciliary tip velocities for the 2 cilium lengths are $u_{\text {tip }}=3.3$ and $11 \mathrm{~mm} \mathrm{~s}^{-1}$, respectively. The latter high, unrestrained tip velocity is in agreement with measurements made by Emlet (1990), see below.

Emlet (1990) experimentally determined velocities of $5.5 \mu \mathrm{m}$ diameter particles at undetermined phases of cilia-beat within the ciliary region at given distances from the surface of tethered larvae of the bivalve Crassostrea gigas (cilium length $=91.5 \mu \mathrm{m}$; angular velocity during power stroke $=159.7 \mathrm{rad} \mathrm{\textrm {s } ^ { - 1 }}$, hence $u_{\text {tip }}=$ $14.6 \mathrm{~mm} \mathrm{~s}^{-1}$ according to Eq. 1) and the gastropod Calliostoma ligatum (cilium length $=126.6 \mu \mathrm{m}$; angular velocity $=130.5 \mathrm{rad} \mathrm{s} \mathrm{s}^{-1}$, hence $u_{\text {tip }}=16.5 \mathrm{~mm} \mathrm{~s}^{-1}$ ). Upstream velocities may be estimated using Eq. (2), assuming that $T_{\mathrm{a}} / T=T_{\mathrm{a}} f=0.024 \times 17=0.4$ (which reduces Eq. (2) to $u_{0}=0.2 u_{\text {tip }}$ ). The result is $u_{0}=2.9$ and $3.3 \mathrm{~mm} \mathrm{~s}^{-1}$, respectively. Assuming an unrestrained cilia velocity $\left(u_{\mathrm{clc}}\right)$ to increase linearly from 0 at the base to the tip value, Emlet's data show local ratios of cilia-to-particle velocity to cover the wide ranges of 1.08 to 3 and 1.23 to 3.3 , respectively, with mean values of 2.07 and 2.15 , respectively. The lower ratios suggest (as hinted by Emlet) that some particles are near cilia in their power stroke phase, hence moving with a velocity close to that of cilia, while other particles are at places with cilia in other phases of beat, hence moving with the local fluid velocity being lower than that of cilia in their power beat. The former may confirm the catch-up hypothesis, particles being pushed with velocity close to that of cilia in their power stroke, while the latter may be indicative of local fluid velocity which covers a range of values.

For the examples given above there is no direct evidence for physical contact between particles and cilia due to 'catch-up', but the particles are being accelerated to a certain velocity $u_{\mathrm{p}}<u_{\mathrm{clc}}$ in the ciliary region, perhaps solely with the fluid. The idea that particles might be transferred to the frontal cilia band, i.e. captured, alone by the unsteady 3-dimensional fluid motion generated by a clc cilia system was pursued by Mayer (1994). His numerical study, modeling Sabella penicillus, confirmed that some particles were in fact captured, but not to the extent that agreed with observed retention efficiencies.

\section{Retention efficiencies and size spectra}

Retention efficiency has been measured in various species of ciliary downstream collecting invertebrates by simultaneous clearance of different sized particles. Because it may be assumed that the retention spec- trum somehow reflects the basic particle capture mechanism, a few comments on this subject seem to be appropriate.

Riisgård et al. (1980) measured the retention spectrum on 5- and 13-d-old veliger (Mytilus edulis) larvae. Clearances of 2.5 to $3.5 \mu \mathrm{m}$ diameter particles were high and the maximum observed, gradually falling to 20 and 10 to $40 \%$ of the maximal value for 1 to $2 \mu \mathrm{m}$ particles and $7.5 \mu \mathrm{m}$ particles, respectively (Fig. 17). Thus, according to this study, particles smaller than about $1 \mu \mathrm{m}$ and larger than 8 to $9 \mu \mathrm{m}$ may not be eaten by the veliger larvae. Quite similar results were obtained by Sprung (1984), who measured retention of
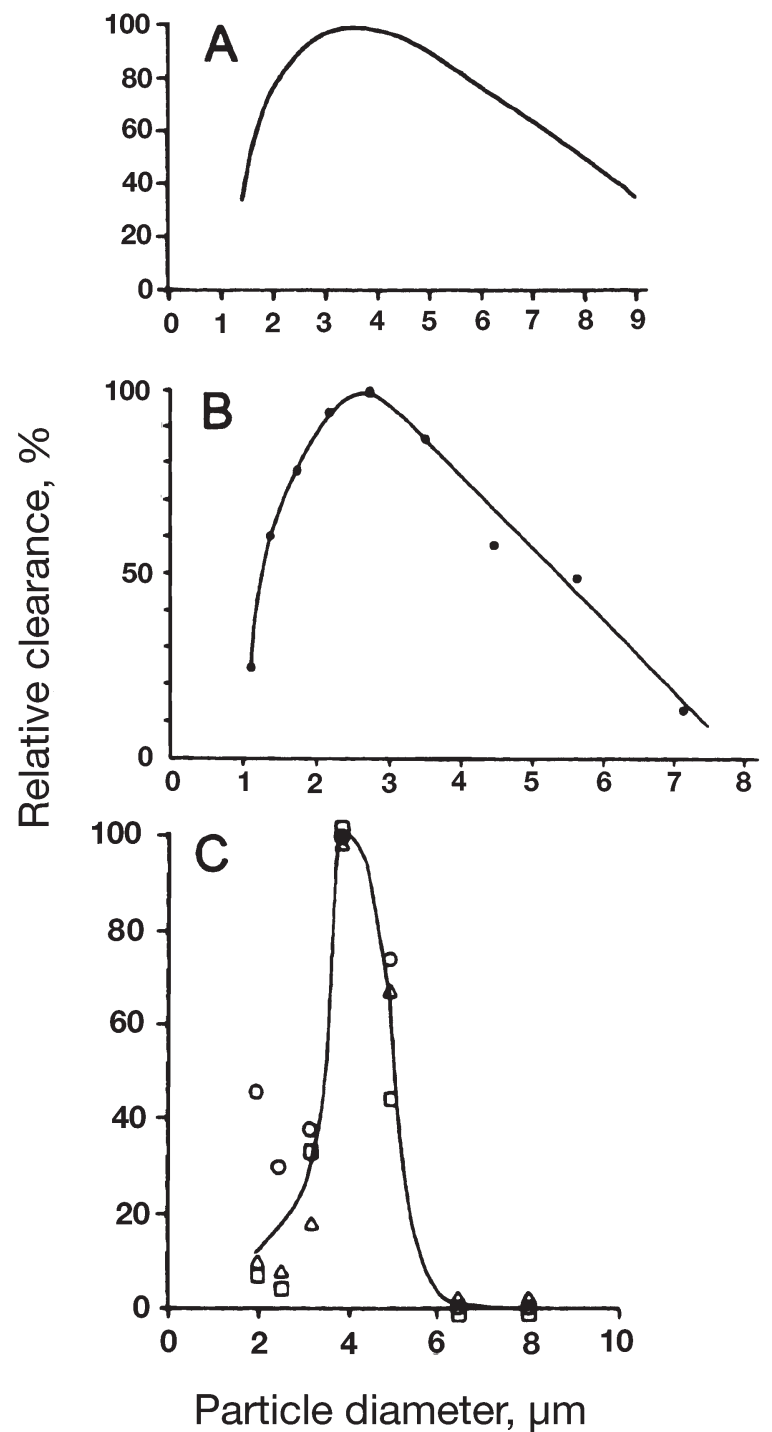

Fig. 17. Retention spectra of bivalve veliger larvae. (A) Mytilus edulis; mean of 2 spectra obtained from $260 \mu \mathrm{m}$ shell length larvae (from Sprung 1984). (B) M. edulis; 5-d-old veliger larvae (from Riisgård et al. 1980). (C) Hard clam Mercenaria mercenaria; 3-d-old larvae (from Riisgård 1988) 
particles in the size range 1.4 to $9 \mu \mathrm{m}$ in $M$. edulis larvae. Here, the retention efficiency was maximal at a particle diameter of $3.5 \mu \mathrm{m}$, while smaller and larger particles were retained with declining efficiency to become about $30 \%$ of the maximum for 1.4 and $9 \mu \mathrm{m}$ particles. Riisgård (1988) reported a similar but more narrow size spectrum (maximal value at $4 \mu \mathrm{m}$, falling to less than 10 to $20 \%$ at 2 and $6 \mu \mathrm{m}$ ) of particles retained by 3-d-old, hard clam larvae (Mercenaria mercenaria) (see Fig. 17). The widening of the size spectum of retained particles with increasing size (and age) of young opisthobranch larvae (Philine aperta) was reported by Hansen (1991). Here, the interciliary spacings of the metatroch $(1.7 \mu \mathrm{m})$ accord with the minimum size of retained particles, including $1.3 \mu \mathrm{m}$ cyanobacteria (Synechococcus sp.), which were cleared at low rates (a few percent) compared to $4.0 \mu \mathrm{m}$ diameter Pavlova lutherii cells, yielding maximal retention. An example of a relatively large particle size $(7 \mu \mathrm{m})$ for maximal retention (with retention declining to a few percent at 2 and $10 \mu \mathrm{m}$ ) was recorded for 3-d-old larvae of the boreal polychaete Mediomastus fragile by Hansen (1993). A rather similar pattern for the lower end of the retention spectrum, as determined for bivalve veliger larvae (Fig. 17), has been found for the adult polychaete Sabella penicillus by Jørgensen et al. (1984), who measured $30 \%$ lower clearance of about $1 \mu \mathrm{m}$ particles compared to the clearance of 3 to $3.5 \mu \mathrm{m}$ diameter particles; but also notable in this connection, the relative clearance declined only slightly for larger particles up to $8 \mu \mathrm{m}$ diameter (Fig. 18).

The above data on size-related retention of particles in ciliary downstream collectors are in conflict with Gallager (1988), who reported higher clearance of 0.5 to $1 \mu \mathrm{m}$ diameter Synechococcus than of $4.5 \mu \mathrm{m}$ diameter Isochrysis galbana. Gallager suggested that production of fecal aggregates may have resulted in gross underestimation of clearance of small particles in previous works employing closed vessels and electronic particle counters, but the criticism has not been confirmed in recent experiments with complex natural suspensions as food (Baldwin 1995), or further substantiated, although repeated (Gallager et al. 1994). However, cultured Synechococcus, as used by Gallager (1988) and Gallager et al. (1994), are usually of larger size $(1.5 \times 6$ to $8 \mu \mathrm{m})$ than free-living cyanobacteria in natural waters (see e.g. Douillet 1993), and this may have led to high clearance of presumed 'small' bacteria in laboratory experiments.

The present work, based on video observations and interpretation of available velocity data on particles, cilia and water, supports the catch-up theory and, as appears from the account below, the theory may also explain the experimentally measured spectra of particle retention in ciliary downstream feeders.
Despite differences in cilia systems among the different species it is presumed that the same basic principles are at play. A plausible explanation of observed spectra of particle retention may be that small particles $(<2 \mu \mathrm{m})$ easily enter the ciliary region, but escape with the through flow because they are not intercepted by the compound cilia, whereas particles larger than a certain optimum size, dependent on the length of the compound cilia, are prevented from entering the ciliary region due to interference with the beating ciliaor they enter only the region near cilia tips-hence are lost. Thus, the optimum particle size is determined by a high probability of, first, entering the ciliary region and, next, being caught-up and separated from the through flow by the action of the compound cilia. According to this explanation the lower size of particles being captured should be independent of age (size) of the animal because it is ultimately determined by the fixed distance between 2 compound cilia in approximately the same phase of an active beat. A particle with a diameter smaller than this distance may
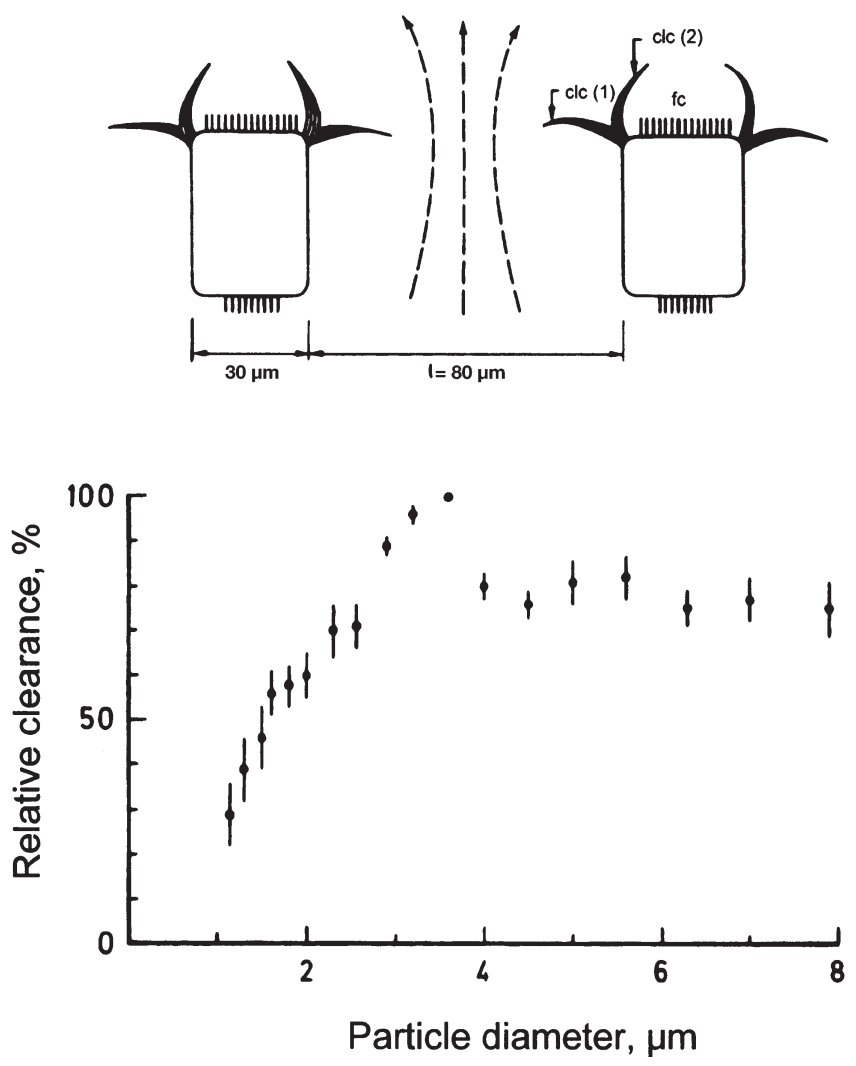

Fig. 18. Sabella penicillus. Upper: cross section of 2 pinnules with opposed compound lateral cilia in resting position at the end over recovery stroke, clc (1), and end of active stroke, clc (2); (fc, frontal cilia) (from Riisgård \& Ivarsson 1990). Lower: retention spectrum expressed as relative clearance of particles of different sizes measured on the adult polychaete (from Jørgensen et al. 1984) 
either not be caught-up or it is liable to roll off a single pushing cilium to subsequently be lost with the through flowing water. The lower size limit for retention of particles by ciliary downstream suspension feeders seems to be fixed and nearly identical for all species studied (i.e. between 1 and $2 \mu \mathrm{m}$ ). This does not mean, however, that, e.g., cyanobacteria cannot be captured and later found in the stomach of veliger larvae (Gallager 1988, Douillet 1993, Gallager et al. 1994); but the volume of water completely cleared of natural, free-living bacteria in the size range 0.5 to $1 \mu \mathrm{m}$ may be (very) small compared to the volume of water simultaneously cleared of optimum sized particles. Only high concentrations of cultured cyanobacteria may result in ingestion of sufficient biomass to partially cover the nutritional needs of downstream ciliary feeders, and concentrations above $5 \times 10^{5}$ Synechococcus cells $\mathrm{ml}^{-1}$ may have a deleterious effect on larval growth (Gallager et al. 1994).

According to the above explanation of the basic principles, the upper end of the retention efficiency spectrum is caused by a 'probability parameter' determined by the length of the compound cilia. Thus, longer cilia imply that larger particles may enter the ciliary region to be caught-up and captured. As shown in Table 2 the length of both prototrochal and metatrochal compound cilia increases with size (age) in ciliary feeding larvae, and, therefore, the retention efficiency of larger particles may be expected to increase with age of the larvae. In the opisthobranch Philine aperta the upper limit for captured particle size was found by Hansen (1991) to increase with larval age from $7 \mu \mathrm{m}$ for newly hatched veligers, with about $10 \mu \mathrm{m}$ long prototrochal cirri, to $>8 \mu \mathrm{m}$ for late stage veligers with 55 to $60 \mu \mathrm{m}$ long prototrochal compound cilia. This supports the catch-up explanation. It is unknown what mechanisms are at play in systems with opposed compound lateral cilia on 2 pinnules forming a channel in, e.g., Sabella penicillus (see cross section of 2 pinnules in Fig. 18), Loxosoma pectinaricola and Spirorbis tridentatus, but it appears that such a geometry may increase the probability of particles to enter the ciliary region. Otherwise it is difficult to explain the relatively high retention of 4 to $8 \mu \mathrm{m}$ particles (Fig. 18) by the relatively short, only about $20 \mu \mathrm{m}$ long, compound lateral cilia (in previous work sometimes referred to as compound laterofrontal cilia) in $S$. penicillus (Mayer 1994). By numerical modeling of the cilia-driven flow in $S$. penicillus (Mayer 2000) showed that particles are captured due to fluid motion alone but with a low rention efficiency of less than about $40 \%$. This result does not contradict the present hypothesis since particle catchup and interception by clc could account for the remaining capture events to match observed efficiencies.

Acknowledgements. H.U.R. and C.N were supported by grants from the Danish National Science Research Council (Nos. 9801440 and 9701589, respectively). We are grateful to Kristineberg Marine Research Station, Sweden, where parts of the work were carried out. Dr Richard R. Strathmann (Friday Harbor Labs, Univ. of Washington), Dr Stefan Mayer (Institute of Mathematical Modeling, Techn. Univ. of Denmark ), and 2 anonymous referees commented on the manuscript. Dr Åse Jespersen and Mr Morten Schiøtt (Zoological Institute, Univ. Copenhagen) are thanked for help with TEM and Mrs Birgitte Rubœk and Mr Gert Brovad (Zoological Museum, Univ. Copenhagen) for help with the illustrations.

Table 2. Length of compound cilia (cirri) in different species of downstream suspension-feeding larvae of different sizes or age

\begin{tabular}{|lcccc|}
\hline & $\begin{array}{c}\text { Shell length } \\
(\mu \mathrm{m})\end{array}$ & $\begin{array}{c}\text { Prototrochal cirri } \\
\text { length }(\mu \mathrm{m})\end{array}$ & $\begin{array}{c}\text { Metatrochal cirri } \\
\text { length }(\mu \mathrm{m})\end{array}$ & Source \\
\hline $\begin{array}{l}\text { Gastropod larvae } \\
\text { Philine aperta }\end{array}$ & 130 & $10-11$ & 10 & Hansen (1991) \\
& 160 & $25-30$ & 15 & Hansen (1991) \\
& 210 & $40-45$ & 15 & Hansen (1991) \\
& 270 & $50-55$ & 15 & Hansen (1991) \\
Calliostoma ligatum & 370 & $55-60$ & & Emlet (1990) \\
Bivalve larvae & 350 & $126.6 \pm 3.0$ & & Strathmann \& Leise (1979) \\
Crassostrea gigas & & & & Emlet (1990) \\
Mercenaria mercinaria & 90 & 30 & & Gallager (1988) \\
Polychaete larvae & $100 \pm 2$ & $32.5 \pm 1.2$ & & Emlet (1998) \\
Mesochaetopterus taylori (3 wk old) & $234 \pm 4$ & $45 \pm 2$ & & Hansen (1993, pers. comm.) \\
Mediomastus fragile (3 d old) & & $42 \pm 1.5$ & $36 \pm 1.5$ & \\
\hline
\end{tabular}


Appendix 1. Drag force on a single cylinder

It is well known that the drag on a single, infinitely long cylinder in cross-flow is an ill-posed problem for creeping flow in the limit of $\operatorname{Re}=0$. However, solutions can be obtained, at $\operatorname{Re}=0$, for a cylinder of finite length, an infinite cylinder in a domain bounded by other surfaces and for an array of parallel cylinders, and, at finite values of $\mathrm{Re}$, for the single infinite cylinder. Expressions for these 4 cases, as well as the numerical value of the force per unit length $F^{\prime}$ due to a normal velocity relative to the cylinder of $\Delta u=1 \mathrm{~mm} \mathrm{~s}^{-1}$, are summarized below. Since $F^{\prime}$ is proportional to $\Delta u$, values of the force for other values of relative velocity are readily evaluated.

For an array of cylinders of diameter $d(=0.4 \mu \mathrm{m})$ spaced a distance $b(=10 d)$ apart, the force per unit length of 1 cylinder becomes (Tamada \& Fujikawa 1957), with $\tau=\pi d / b$,

$F^{\prime}=b \Delta p=8 \pi \mu \Delta u /\left(1-2 \ln \tau+\tau^{2} / 6\right)=8.07 \times 10^{-6} \mathrm{~N} \mathrm{~m}^{-1}$ (A1)

For a cylinder of finite length $L(=25 \mu \mathrm{m}=62.5 d)$ the force per unit length becomes (Lighthill 1976; see also Silvester 1988)

$$
F^{\prime}=8 \pi \mu \Delta u /[1+2 \ln (0.22 L / d)]=4.3 \times 10^{-6} \mathrm{~N} \mathrm{~m}^{-1}
$$

A cylinder moving in a confined fluid volume, for example a cylinder of diameter $D_{\text {c }}($ e.g. $=20 \mathrm{~d})$, leads to the expression (Happel \& Brenner 1965, p. 343)

$$
F^{\prime}=8 \pi \mu \Delta u /\left[1+2 \ln \left(D_{\mathrm{c}} / d\right)\right]=3.85 \times 10^{-6} \mathrm{~N} \mathrm{~m}^{-1}
$$

Using the Oseen approximation, solutions depending on the Reynolds number have been obtained by singular perturbation (Van Dyke 1964, p. 164; see also Happel \& Brenner 1965, p. 48) of form

$F^{\prime}=4 \pi \mu \Delta u\left[\Delta_{1}-0.87 \Delta_{1}{ }^{3}+o\left(\Delta_{1}{ }^{4}\right)\right] ; \Delta_{1}=[\ln (8 / \operatorname{Re})-0.077]^{-1}$ which for small values of the Reynolds number, say $\mathrm{Re}=$ $\rho d \Delta u / \mu=4 \times 10^{-4}$, can be written as

$$
F^{\prime}=8 \pi \mu \Delta u /[2 \ln (8 / \mathrm{Re})-0.154]=1.37 \times 10^{-6} \mathrm{~N} \mathrm{~m}^{-1}
$$

Note the similarity in mathematical form and that numerical values for the given set of parameters are approximately of the same order of magnitude.

\section{LITERATURE CITED}

Baba SA (1972) Flexural rigidity and elastic constant of cilia. J Exp Biol 56:459-467

Baldwin BS (1995) Selective particle ingestion by oyster larvae (Crassostrea virginica) feeding on natural seston and cultured algae. Mar Biol 123:95-107

Baltzer F (1917) Echiuriden 1. Teil: Echiurus abyssalis. Fauna und Flora des Golfes von Neapel, Vol 34. R. Friedländer, Berlin

Cheer AYL, Koehl MAR (1987) Paddles and rakes: fluid flow through bristled appendages of small organisms. J Theor Biol 129:17-39

Douillet P (1993) Bacterivory in Pacific oyster Crassostrea gigas larvae. Mar Ecol Prog Ser 98:123-134

Emlet R (1990) Flow fields around ciliated larvae: effects of natural and artificial tethers. Mar Ecol Prog Ser 63: 211-225

Emlet RB, Strathmann RR (1994) Functional consequences of simple cilia in the mitraria of oweniids (an anomalous larva of an anomalous polychaete) and comparisons with other larvae. In: Wilson WH, Stricker SA, Shinn GL (eds) Reproduction and development of marine invertebrates. The Johns Hopkins University Press, Baltimore, p 143-157 Erdmann W (1935) Untersuchungen über die Lebensgeschichte der Auster. Nr. 5. Über die Entwicklung und die Anatomie der 'ansatzreifen' Larve von Ostrea edulis mit Bemerkungen über die Lebensgeschichte der Auster. Helgol Wiss Meeresunters 19(6):1-25

Funch P, Kristensen RM (1995) Cycliophora is a new phylum with affinities to Entoprocta and Ectoprocta. Nature 378: 711-714

Funch P, Kristensen RM (1997) Cycliophora. In: Harrison FW (ed) Microscopic anatomy of invertebrates, Vol 13. WileyLiss, New York, p 409-474

Gallager SM (1988) Visual observations of particle manipulation during feeding in larvae of a bivalve mollusc. Bull Mar Sci 43:344-365

Gallager SM, Waterbury JB, Stoecker DK (1994) Efficient grazing and utilization of the marine cyanobacterium Synechococcus sp. by larvae of the bivalve Mercenaria mercenaria. Mar Biol 119:251-259

Grant NJ (1981) A scanning electron microscopic study of larval development in the marine polychaete, Galeolaria caespitosa Lamarck (Serpulidae). Cell Tissue Res 215: 171-179

Gros O, Frenkiel L, Mouëza M (1997) Embryonic, larval, and postlarval development in the symbiotic clam Codakia orbicularis (Bivalvia: Lucinidae). Invertebr Biol 116: 86-101

Hansen B (1991) Feeding behaviour in larvae of the opisthobranch Philine aperta. II. Food size spectra and particle selectivity in relation to larval behaviour and morphology of the velar structures. Mar Biol 111:263-270

Hansen B (1993) Aspects of feeding, growth and stage development by trochophora larvae of the boreal polychaete Mediomastus fragile (Rasmussen) (Capitellidae). J Exp Mar Biol Ecol 166:273-288

Happel J, Brenner H (1965) Low Reynolds number hydrodynamics. Prentice-Hall, Inc, Englewood Cliffs, NJ

Hatschek B (1878) Studien über die Entwicklungsgeschichte der Anneliden. Arb Zool Inst Univ Wien 1:277-404

Hermans CO (1978) Metamorphosis in the opheliid polychaete Armandia brevis. In: Chia FS, Rice ME (eds) Settlement and metamorphosis of marine invertebrate larvae. Elsevier, New York, p 113-126

Jägersten G (1972) Evolution of the metazoan life cycle. Academic Press, London

Jørgensen CB, Kiørboe T, Møhlenberg F, Riisgård HU (1984) Ciliary and mucus net filter feeding, with special reference to fluid mechanical characteristics. Mar Ecol Prog Ser 15:283-292

Lacalli T (1984) Structure and organization of the nervous system in the trochophore larva of Spirobranchus. Phil Trans R Soc Lond Biol Sci 306:79-135

Lighthill J (1976) Flagellar hydrodynamics. SIAM Rev 18: $161-230$

Malakhov VV (1990) Description of the development of Ascopodaria discreta (Coloniales, Barentsiidae) and discussion of the Kamptozoa status in the animal kingdom. Zool Zh 69:20-30 (in Russian with English summary)

Mayer S (1994) Particle capture in the crown of the ciliary suspension feeding polychaete Sabella penicillus: video recordings and interpretations. Mar Biol 119:571-582

Mayer S (2000) Numerical simulation of flow fields and particle trajectories in ciliary suspension feeding. Bull Math Biol (in press) 
McHugh D (1997) Molecular evidence that echiurans and pogonophorans are derived annelids. Proc Natl Acad Sci USA 94:8006-8009

Melone G, Ricci C (1995) Rotatory apparatus in bdelloids. Hydrobiologia 313/314:91-98

Newby WW (1940) The embryology of the echiuroid worm Urechis caupo. Mem Am Phil Soc 16:1-219

Nielsen C (1987) Structure and function of metazoan ciliary bands and their phylogenetic significance. Acta Zool (Stockh) 68:205-262

Nielsen C (1995) Animal evolution: interrelationships of the living phyla. Oxford University Press, Oxford

Nielsen C, Pedersen KJ (1979) Cystid structure and protrusion of the polypide in Crisia (Bryozoa, Cyclostomata). Acta Zool (Stockh) 60:65-88

Nielsen C, Riisgård HU (1998) Tentacle structure and filterfeeding in Crisia eburnea and other cyclostomatous bryozoans, with a review of upstream-collecting mechanisms. Mar Ecol Prog Ser 168:163-186

Nielsen C, Rostgaard J (1976) Structure and function of an entoproct tentacle with a discussion of ciliary feeding types. Ophelia 15:115-140

Nielsen NF, Larsen PS, Riisgård HU, Jørgensen CB (1993) Fluid motion and particle retention in the gill of Mytilus edulis: video recordings and numerical modelling. Mar Biol 116:61-71

Riisgård HU (1988) Feeding rates in hard clam (Mercenaria mercenaria) veliger larvae as a function of algal (Isochrysis galbana) concentration. J Shellfish Res 7:377-380

Riisgård HU, Ivarsson NM (1990) The crown-filament pump of the suspension-feeding polychaete Sabella penicillus: filtration, effects of temperature, and energy cost. Mar Ecol Prog Ser 62:249-257

Riisgård HU, Larsen PS (2000) A comment on experimental techniques for studying particle capture in filter-feeding bivalves. Limnol Oceanogr 45:1192-1195

Riisgård, HU, Manríquez P (1997) Filter-feeding in fifteen marine ectoprocts (Bryozoa): particle capture and water pumping. Mar Ecol Prog Ser 154:223-239

Riisgård HU, Randløv A, Kristensen SP (1980) Rates of water processing oxygen consumption and efficiency of particle retention in veligers and young post-metamorphic Mytilus edulis. Ophelia 19:37-47

Riisgård HU, Larsen PS, Nielsen NF (1996) Particle capture in the mussel Mytilus edulis: the role of laterofrontal cirri. Mar Biol 127:259-266

Segrove F (1941) The development of the serpulid Pomato-

Editorial responsibility: Tom Fenchel (Contributing Editor), Helsingør, Denmark ceros triqueter L. Q J Microsc Sci 82:467-540

Silvermann H, Lynn JW, Achberger EC, Dietz TH (1996a) Gill structure in zebra mussels: bacteria-sized particle filtration. Am Zool 36:373-384

Silverman H, Lynn JW, Dietz TH (1996b) Particle capture by gills of Dreissena polymorpha: structure and function of laterofrontal cirri. Biol Bull 191:42-54

Silverman H, Lynn JW, Dietz TH (2000) In vitro studies of article capture and transport in suspension-feeding bivalves. Limnol Oceanogr 45:1199-1203

Silvester S (1988) Hydrodynamics of flow in Mytilus edulis. J Exp Mar Biol Ecol 120:171-182

Sleigh MA, Holwill MEJ (1969) Energetics of ciliary movement in Sabellaria and Mytilus. J Exp Biol 50:733-743

Sprung M (1984) Physiological energetics of mussel larvae (Mytilus edulis). II. Food uptake. Mar Ecol Prog Ser 17: 295-305

Strathmann RR, Leise E (1979) On feeding mechanisms and clearance rates of molluscan veligers. Biol Bull 157:524-535

Strathmann RR, McEdward LR (1986) Cyphonautes' ciliary sieve breaks a biological rule of inference. Biol Bull 171: 694-700

Strathmann RR, Jahn T, Fonesca JRC (1972) Suspension feeding by marine invertebrate larvae: clearance of particles by ciliated bands of a rotifer, pluteus, and trochophore. Biol Bull 141:505-519

Tamada K, Fujikawa H (1957) The steady 2-dimensional flow of viscous fluid at low Reynolds numbers passing through an infinite row of equal parallel circular cylinders. Q J Mech Appl Math 10:426-432

Timoshenko S, Goodier JN (1951) Theory of elasticity. McGraw-Hill Book Co Inc, New York

Van Dyke M (1964) Perturbation methods in fluid mechanics. Academic Press, New York

Waller TR (1981) Functional morphology and development of veliger larvae of the European oyster, Ostrea edulis Linné. Smithson Contrib Zool 328:1-70

Werner B (1955) Über die Anatomie, die Entwicklung und Biologie des Veligers und der Veliconcha von Crepidula fornicata L. (Gastropoda, Prosobranchia). Helgol Wiss Meeresunters 5:169-217

Wilson DP (1982) The larval development of three species of Magelona (Polychaeta) from localities near Plymouth. J Mar Biol Assoc UK 62:385-401

Woltereck R (1902) Trochophora-Studien I. Histologie der Larve und die Entstehung des Annelids bei den Polygordius-Arten der Nordsee. Zoologica (Stuttg) 13:1-71

Submitted: November 23, 1999; Accepted: April 4, 2000

Proofs received from author(s): November 2, 2000 